\title{
Sub-optimal international portfolio allocations and cost of capital
}

\begin{abstract}
Finance theory suggests that the optimal international equity portfolio investment by home and foreign investors reduces cost of capital through international risk sharing and capital market integration. However, the empirical evidence is inconsistent with theory as a number of studies show investors exhibit cross-country biases in their international portfolio investments, known as home and foreign biases. In this study we investigate the implications of home and foreign biases on cost of capital. Using data from 44 countries over a period of 2001-2014, we provide strong evidence that countries which experience higher home bias are associated with a higher cost of capital. Similarly, we also find that countries which are more favoured by foreign investors, relative to the theoretical predictions, are associated with a lower cost of capital.
\end{abstract}

JEL classification: F3, G1

Keywords: Market integration; International Capital Asset Pricing Model; Equity home bias; Equity foreign bias; Cost of capital 


\section{Introduction}

The International Capital Asset Pricing Model (ICAPM) suggests that financial liberalization, which formally allows inward and outward international portfolio investments, should integrate the domestic capital market with world capital markets. Increasing market integration, driven by financial globalization, should reduce a country's cost of capital (see Errunza and Losq, 1985; Errunza and Miller, 2000). ${ }^{1}$ Errunza (2001) notes that the essence of the inverse relation between cost of capital and market integration is the migration from local pricing and narrow shareholder base to global pricing and a more diversified international shareholder base enhancing international risk sharing. Further, Bekaert and Harvey (2003) suggest that when domestic capital market integrate with world capital markets; the volatility of world capital markets become more relevant relative to domestic capital market in the pricing of local securities. As the volatility of world capital market is lower than local capital market, cost of capital should be lower for a country which is more integrated with world capital markets.

Although there is a strong theoretical case for a resultant fall in cost of capital, Bekaert and Harvey (2003) note that despite formal financial liberalization, i.e. removal of direct legal restrictions, there can be significant indirect barriers (such as information asymmetry, political and financial policy risks, higher trading costs etc.) to international portfolio investments. Such indirect barriers deter investors from investing optimally across the global markets leading to market segmentation or only mild integration. In terms of optimality of portfolio allocation, the ICAPM prescribes that equity portfolio investors should hold a well-diversified world portfolio as the benchmark (see Solnik, 1974; Adler and Dumas, 1983; Lewis, 1999). However, in the presence of indirect barriers to international

\footnotetext{
${ }^{1}$ Cost of capital is an important input in capital budgeting evaluation of investment projects. Higher cost of capital leads to lower net present value undermining the acceptance possibilities of prospective projects. Such non-feasibility of investment projects, particularly owing to higher cost of capital, harms the prospects of making positive effects in the real economy leading to slower growth and lost employment opportunities.
} 
investments, world capital markets are, to some extent, segmented as equity portfolio investors in both the developed and emerging markets exhibit varying degrees of home and foreign biases in their international portfolio allocations. ${ }^{2}$ Home bias relates to the phenomenon of sub-optimally higher home investments by domestic investors, i.e. overweighting of the home market relative to the ICAPM benchmark. Similarly, foreign bias refers to the tendency of foreign investors to over or under allocate foreign markets compared to the ICAPM benchmark (for details on the difference between home and foreign bias, see Dahlquist et al. 2003; Chan et al. 2005 and this discussed further in sections 3.2.1 and 3.2.2 of this paper). ${ }^{3}$

A number of studies theoretically and empirically provide evidence on the partial integration/segmentation of domestic capital markets from world capital markets, thereby inhibiting optimal international risk sharing (see Errunza and Losq, 1985; Stulz, 1999; Chaieb and Errunza, 2007). Clearly, drawing on evidence of sub-optimal international portfolio allocations and the varying degree of market integration/segmentation, we test the following two related hypotheses.

$H_{1}$ : Higher degree of home bias is associated with higher cost of capital.

$H_{2}$ : Higher degree of foreign bias is associated with lower cost of capital.

In other words, theory suggests that the higher degree of home bias, implying lower international risk sharing (i.e. lower integration with world capital markets), should be associated with a higher cost of capital. Similarly, economic reasoning also conjecture that

\footnotetext{
${ }^{2}$ See Bekaert et al. (2011) and Carrieri et al. (2013) for recent evidence on market segmentation. For evidence on causes of home and foreign/biases, see Lewis (1999), Chan et al. (2005), Bekaert and Wang (2010), Mishra (2014), Kim et al. (2015), and O'Hagan-Luff and Berrill (2015).

${ }^{3}$ In our study, higher home bias refers to greater home allocations relative to benchmark whereas higher foreign bias refers to higher foreign cross-country allocations relative to benchmark. Hence, higher home bias from domestic investors should lead to greater market segmentation but higher foreign bias from foreign investors should lead to greater market integration.
} 
higher levels of foreign bias, suggesting higher international risk sharing (i.e. higher integration with world capital markets), should be associated with a lower cost of capital.

Using five proxies of cost of capital and extensive robustness tests, our study provides a comprehensive investigation of how variations in sub-optimal international portfolio allocations (i.e. home and foreign bias) affect the cross-country cost of capital. In addition to using the two conventional proxies for cost of capital, i.e. dividend yield and historical risk premium, we also use the sovereign bond rating as an implied cost of capital, an expected country equity risk measure (see Jewel and Livingston, 1998; Damodaran, 2012), and finally in our robustness test we use Tobin's Q as an additional valuation proxy capturing the inverse feature of cost of capital. The use of multiple finance based proxies help address some of the limitations and sensitivities of accounting based implied cost of capital proxies. The proxy variables account for country default risk and the use of these proxies offers new insights with regards to the implications of foreign and home bias on finance based proxy variables.

Our study reports the following findings. First, the univariate figures of all cost of capital measures strongly suggest that developed countries exhibit lower cost of capital relative to their emerging market counterparts. This implies that compared to investments in emerging markets, investors apply significantly lower value of discount rates when evaluating projects in developed markets. Second, in terms of international risk sharing, portfolio investors in developed markets enjoy significant international risk sharing as reported by cross-country figures of home and foreign biases. Developed markets' portfolio investors exhibit significantly lower home bias relative to those in emerging markets. Similarly, foreign portfolio investors seem to prefer developed markets more in their crosscountry equity portfolio allocations compared to emerging markets. More importantly, we supplement the literature by providing evidence that the phenomena of sub-optimal international allocations are not only observed in the aggregate and macro data (see Chan et 
al. 2005 and Bekaert and Wang, 2010) but also by individual global equity funds, which are managed by sophisticated managers with the sole purpose of optimal global diversification.

Finally, consistent with theory, our empirical analyses provide strong evidence that higher degree of home bias is associated with a higher cost of capital. This strongly indicates that countries which exhibit home bias in their international portfolio investments display lower degree of integration with world capital markets leading to higher cost of capital. Correspondingly, we also find that higher degree of foreign bias towards a host country (i.e. more favourable allocation by foreign investors) is related to a lower cost of capital benefiting from higher degree of market integration.

Our study makes two important contributions to the literature. First, existing studies predominantly examine the causes of home and foreign bias (see Chan et al. 2005; Gelos and Wei, 2005; Bekaert and Wang, 2010) investigating the implications of these biases. In this paper we investigate whether varying degrees of home and foreign biases have implications for cost of capital. The relevant literature is either based on event studies, investigating how cost of capital changes in the post financial liberalization period, or analyses the influence of depository receipts on cost of capital. ${ }^{4}$ Similarly, a number of studies investigate the impact of floating depository receipts (American/Global Depositary Receipts ADRs/GDRs) on cost of capital..$^{5}$ Unlike these studies, in this paper we use direct measures of sub-optimal international portfolio investments (i.e. home and foreign bias) to study their effects on cost of capital. The paper extends Chan et al. (2009) by introducing new finance based proxy variables for cost of capital and we also control for local risk factors. The finance based proxy

\footnotetext{
${ }^{4}$ For example, Kim and Singal (2000) and Chari and Henry (2004) show that the post financial liberalization cost of capital of the liberalized economy significantly decreases. Stulz (1999) and Henry (2000) also find similar results, suggesting that the reduction in cost of capital is driven by increased risk-sharing and improved corporate governance. De Jong and de Roon (2005) show that the increased time-varying integration (i.e. the process of gradual financial liberalization of the domestic equity market) is associated with a reduction in cost of capital.

${ }^{5}$ For example, Foerster and Karolyi, (1999), Errunza and Miller (2000) and Karolyi (2004) demonstrate that firms issuing ADRs experience a fall in cost of capital, driven by the increased global risk sharing effect. For more recent evidence see Edison and Warnock (2008) and Hail and Leuz (2009).
} 
variables are used to investigate the possibility of causality with the biases. We went further to provide robustness to the study by examining the implications of global fund foreign bias on firm performance via Tobin's Q. We also strengthen Chan et al. (2009) by addressing the concern of possible reverse causality using lagged values, dynamic generalized methods of moment estimation (GMM), and the Heckman selection model.

Second, the aggregated measures of foreign and home bias used in existing studies do not consider the individual objectives or focus of funds. The use of the fund level data provides new insight with regards to the implications on cost of capital of funds that seek global diversification but deviate from holding ICAPM benchmark portfolio weight. Although on a theoretical basis, each fund should be globally diversified, in practice a fund's objective could be single country, single region or global diversification, targeted to suit the preferences of different investor groups. For example, if the focus of the fund is diversification only within the European Union (EU), it will have no allocations across countries outside the EU. Additionally, if the focus of a fund is on a single country or region, it will significantly affect the aggregate measure of home and foreign bias. To address this issue of potential bias in the measure of sub-optimal allocations of international investors, we construct a highly conservative foreign bias measure that uses unique micro firm level global funds' allocation data across 44 countries. The global funds that we use have the sole objective of global diversification across all investable countries as most of them use the 45 countries' MSCI AC index. The use of funds data that focus mainly on global diversification provide the most restrictive and unbiased measure of foreign bias, significantly reducing what we refer to as the fund-focus bias in the construction of foreign bias measures used in the existing literature.

The remainder of our paper is structured as follows. Section 2 describes the theoretical framework we use to model cost of capital against home and foreign biases. 
Section 3 describes the data used in our study. Section 4 presents and discusses the empirical results and finally, section 5 concludes the paper.

\section{Theoretical framework}

Following the theoretical framework of Lewis (1999) the standard model showing the pricing relation against the sub-optimal holdings of all domestic investors in country $l$ is shown in equation (1) below: ${ }^{6}$

$$
E\left(r_{l}\right)=\gamma \frac{w_{l}-w_{l}^{*}}{1-w_{l}^{*}} \operatorname{Var}\left(r_{l}\right)+\gamma \frac{1-w_{l}}{1-w_{l}^{*}} \operatorname{Cov}\left(r_{l}, r_{w}\right)
$$

where $E\left(r_{l}\right)$ is country l's risk premium, $\gamma$ is relative risk aversion parameter which is assumed to be identical for all investors in the country $l . w_{l}$ is the proportion of domestic investors portfolio allocated to domestic equities of country $l . w_{l}^{*}$ is country $l$ 's market share in the world market portfolio. $\operatorname{Var}\left(r_{l}\right)$ is the variance of local market return of country $l$ with $\operatorname{Cov}\left(r_{l}, r_{w}\right)$ being the covariance between local market return and world market return $\left(r_{w}\right)$. If we assume that domestic investors in country $l$ only invest in local securities then equation (1) reduces to:

$$
E\left(r_{l}\right)=\gamma \operatorname{Var}\left(r_{l}\right)
$$

When local investors invest mainly in domestic equities, the expected return of their portfolio is proportional to the variance of the domestic market return. This conjecture in the pricing modelling is similar to that of an asset pricing modelling in a completely segmented market. Equation (2) shows the impact of complete home bias on cost of capital. In the absence of international diversification, the price of the domestic market portfolio is determined only by its own return variance. However, in a situation where local investors do

\footnotetext{
${ }^{6}$ As it is standard model we do not report the derivation.
} 
not exhibit home bias and keep domestic equity in relation to the country's share in the world-market portfolio, i.e. $w_{l}=w_{l}^{*}$, equation (1) is then expressed as:

$$
E\left(r_{l}\right)=\gamma \operatorname{Cov}\left(r_{l}, r_{w}\right)
$$

This is the case where domestic investors do not exhibit any home bias. Such relation signifies that domestic investors are diversifying their portfolio internationally, implying the local stock market being fully integrated with the world capital market.

Although the above two situations (i.e. equation 2 and 3) are rare cases, in reality equity investors demonstrate varying degrees of home bias (Chan et al. 2005). The percentage of their domestic equity holdings falls within the interval of $\left(w_{l}^{*}, 1\right)$ and thus equation $(1)$ could be written as:

$$
E\left(r_{l}\right)=\gamma \frac{w_{l}-w_{l}^{*}}{1-w_{l}^{*}}\left\{\operatorname{Var}\left(r_{l}\right)-\operatorname{Cov}\left(r_{l}, r_{w}\right)\right\}+\gamma \operatorname{Cov}\left(r_{l}, r_{w}\right)
$$

Equation (4) demonstrates the association between the degrees of home bias on cost of capital. The greater the value of the weight the local investors hold their domestic country's equities $\left(w_{l}\right)$, the higher the degree of home bias they exhibit. ${ }^{7}$ The term $\left(w_{l}-w_{l}^{*}\right) /\left(1-w_{l}^{*}\right)$ in equation (4) could be interpreted as the degree of market integration within the framework of Bekaert and Harvey (1995). A country with a lower level of integration will have a larger value of $w_{l}$ leading to higher degree of home bias. Such higher level of home bias or market segmentation will therefore result in higher cost of capital if the following condition prevails:

$$
\operatorname{Var}\left(r_{l}\right)>\operatorname{Cov}\left(r_{l}, r_{w}\right)
$$

\footnotetext{
${ }^{7}$ Bekaert and Harvey (1995) develop a regime-switching model to show the effects of the differing proportions of market segmentation which is equal to equation (4).
} 
It is well documented in the literature that the $\operatorname{Cov}\left(r_{l}, r_{w}\right)$ is smaller than $\operatorname{Var}\left(r_{l}\right)$ (see Stulz, 1999).

So far the above framework only focuses on allocation by domestic investors in domestic market. In theory foreign investors should also benchmark the optimal allocation, i.e. $w_{l}^{*}$ for country $l$. However, studies (e.g. Chan et al. 2005) show that in case of bilateral foreign portfolio investments, foreign investors relatively under (over) allocate the benchmark weight suggested by ICAPM exhibiting what is termed as foreign bias. Suppose if the foreign allocation from country $k$ into country $l$ is $w_{k l}$ then foreign bias for country $l$ exhibited by investors in country $k$ is defined as $\log \left(w_{k l} / w_{l}^{*}\right)$. This ratio could be negative (under-allocation) or positive (over-allocation). Clearly, on average, higher degree of foreign bias from all foreign investors for country $l$ imply relatively lower home bias. This suggests that higher (lower) degree of foreign bias should be associated with a higher (lower) degree of market integration, which in turn, should be related to lower (higher) cost of capital for investors in country $l$. Thus, this measure of foreign bias constructed in the literature should be inversely related to cost of capital.

\section{Data}

We describe the four different costs of capital measures we use in our primary analysis, ${ }^{8}$ followed by a measure of home bias and two measures (using macro and micro data) of foreign biases. Finally, following the existing literature we discuss the control variables that could potentially compete with our home bias and foreign biases measures.

\subsection{Proxies of cost of capital}

\footnotetext{
${ }^{8}$ We also use an additional proxy (Tobin's $Q$ ) for cost of capital in our robustness section 4.4.1.
} 
We use the following four variables as proxies for country level cost of capital: historical realized market risk premium, a sovereign bond credit-risk rating based implied cost of capital, Damodaran's (2012) default spread-based country risk premium, and the dividend yield.

\subsubsection{Historical realized market risk premium}

The first measure we use is the historical realized return of the market $(H R R m)$ which is the historical average of excess country equity market return over the risk free rate. For each year, the yearly average stock market returns are computed using the monthly US dollar country stock market indices sourced from Morgan Stanley Capital International (MSCI). Since all returns are denominated in US dollars, we use the yearly average of the monthly return on US Treasury bills as a proxy for the risk free rate for all countries. One of the fundamental assumptions of using the historical risk premium as a proxy for the expected risk premium is that the long term average premium is mean reverting. Although this measure can be used for developed markets where long historical data are available, yielding a lower degree of standard errors, it is not appropriate for most of the emerging markets, which have a relatively shorter history of stock return data. We address this issue by using alternative average risk premium measures based on sovereign country credit risk ratings. The first is the proxy of implied cost of capital, estimated using the sovereign credit ratings $(r C r e d)$. The second is Damodaran's (2012) country risk premium which is based on sovereign default spread but adjusted for relative risk of equity versus bond markets' expected return $(C E R P)$.

\subsubsection{Sovereign credit-risk rating measures of cost of capital}

Following Jewel and Livingston (1998), for each country we use sovereign bond risk rating, denominated in foreign currency, as the proxy of implied cost of capital. The basic idea is that sovereign country credit ratings display fundamental forward looking information 
on country's risk and, unlike expected returns measures based on historical data, do not suffer from the noise of past shocks to a country's growth opportunities. Previous studies show that country credit-risk rating correlates highly with implied cost of capital, and thereby could be used as an alternative proxy of cost of capital. ${ }^{9}$ We obtain country credit-risk ratings of 10year local currency denominated sovereign bonds (see Damodaran, 2012). Following Reeb et al. (2001) we convert the qualitative credit ratings into numerical values $(A A A=1, A A+=2$, $A A=3 \ldots . D=22)$ and take their natural $\log$ into our regressions. We expect a positive (negative) association between $r$ Cred and home bias (foreign bias) in our estimations.

\subsubsection{Country equity risk premium}

We also use the country equity risk premium $(C E R P)$ constructed and maintained by Damodaran (2012). The CERP measure follows the concept of demanding incremental CERP for investing in a particular market relative to a mature market as a base country. Damodaran (2012) uses the United States as the base country and S\&P 500 as the representative stock market. For each country, the incremental premium relative to the base country, which reflects the additional country risk premium, is computed by taking the default spread (over the base country) following Moody's risk ratings of sovereign bonds in local currency. The resultant premium is subsequently scaled by the ratio of the country's equity market volatility to bond market volatility. For instance, in calculating the equity risk premium for Brazil, Damodaran (2012) first determines the default risk premium spread of a 10-year local currency denominated government bond over the 10-year US sovereign bond. The resultant premium is subsequently adjusted for the additional risk of the equity market by scaling it with the ratio of standard deviations of Brazil's equity to bond market. The standard deviations of the bond market are estimated using returns on the 10-year sovereign bonds and

\footnotetext{
9 For example, Hail and Leuz (2006) find the sovereign credit ratings measure has an average correlation coefficient of 0.64 with the implied cost of capital. Further, Bhattacharya and Daouk (2002) also suggest that country credit rating is a reliable proxy for ex ante risk exposure, particularly for segmented emerging countries.
} 
that of the local equity market using the national stock index, e.g. Bovespa for Brazil. For more details see Damodaran (2012).

\subsubsection{Dividend yield}

Following extensive use in the literature (see Bekaert and Harvey, 2000) we use dividend yield (DY) as an additional proxy for cost of capital. Bekaert and Harvey (2005) also show that relative to historical realized returns, $D Y$ is a reasonable proxy for cost of capital, particularly for emerging markets where returns are relatively more volatile than those of their developed market counterparts. We obtain $D Y$ data for all countries from Thompson Reuters and the World Federation of Exchanges.

\subsection{Home and foreign bias measures}

We use three different datasets to construct the measure of home and foreign bias exhibited by portfolio investors in the country allocations. The first dataset is the standard aggregate country level cross-country equity portfolio holding (in USD millions) data sourced from the Coordinated Portfolio Investment Survey (CPIS) of the International Monetary Fund (IMF). The CPIS collect data on stocks of cross-border holdings of equities for 76 countries (see Bekaert and Wang, 2010). We use the annual cross-country portfolio holdings CPIS data for the period 2001-2014 to construct our equity home bias (CPIS_HB) and equity foreign bias (CPIS_FB) measures, as described below. Dictated by the availability of data for our key cost of capital proxies and other control variables, we use data on 44 countries-excluding only one of the 45 countries comprising the MSCI All Country Index.

Second, we use unique fund level country allocation data from Emerging Portfolio Fund Research $(E P F R)$ to create the global fund's foreign bias $\left(G F_{-} F B\right)$ measure. ${ }^{10} E P F R$ provides asset allocation data trading in traditional and alternative funds domiciled globally.

${ }^{10}$ EPFR is used in finance research to address a number of different issues (see, Gelos and Wei, 2005; Jotikasthira et al. 2012). 
The aim of the country allocations is to provide a complete and comprehensive picture of fund managers' allocations driving global markets. We use the yearly average (based on monthly observations) country allocations of 122 global equity funds - the total size of all the funds approximately US $\$ 120$ billion. These funds are domiciled across nine countries for the period of 2001-2014. Since these are purely global funds, we expect the foreign bias to be minimal compared to the CPIS aggregate data which include various (undisclosed) funds' type and style. To maintain consistency with the CPIS data, we adopt the EPFR sample period (2001-2014). Furthermore, since the funds are domiciled in nine countries, we are unable to construct a robust measure of home bias due to the smaller number of observations for our empirical analysis (90 observations only). ${ }^{11}$ Finally, for the construction of ICAPM benchmark allocation, we use the country level market capitalization figures for S\&P/IFC obtained from the World Development Indicator $(W D I)$ of the World Bank.

\subsubsection{Equity home bias}

The equity home bias $(E H B)$ measure captures the extent to which domestic investors overweight their domestic equity market relative to the prescription of the ICAPM benchmark. Following the existing literature (see Ahearne et al. 2004; Chan et al. 2005) we define home bias as:

$$
E H B_{l t}=\log \left(\frac{W_{l l t}}{W_{l t}^{*}}\right)
$$

where $w_{l l t}$ represents domestic investors' weightings in the domestic market capitalization of country $l$ for the period $t$ and is defined as:

$$
w_{l l t}=\frac{h_{l l t}}{G P H_{l t}}
$$

\footnotetext{
${ }^{11}$ Detailed summary information on EPFR funds, for instance, the yearly average size of the funds is available from the author on request.
} 
where $h_{l l t}$ is the market value of domestic stocks held by all domestic investors in their domestic market $l$ and $G P H_{l t}$ is the total market value of domestic investors' global holdings for the period $t$ across all 44 countries including domestic market. $w_{l t}^{*}$ is the ICAPM world benchmark allocation for country $l$ for time period $t$, which is the same for all investors in all countries and is defined as:

$$
w_{l t}^{*}=\frac{\operatorname{cap}_{l t}}{\sum_{l=1}^{44} \operatorname{cap}_{l t}}
$$

where $\operatorname{cap}_{l t}$ is the total market capitalization of country $l$ and is obtained from WDI. A value of zero for $E H B_{l t}$ in equation (6) indicates that investors have no bias towards their home market, while positive values show the presence of home bias. Equation (8) shows the market capitalization of country $l$ divided by the market capitalization of the world-market portfolio. $^{12}$

It is worth noting that CPIS only reports the bilateral foreign equity portfolio holdings with no investments in domestic markets for each host country $l$. Following the literature (see Fidora et al. 2007) the construction of domestic holdings $\left(h_{l l t}\right)$ and global portfolio holdings of domestic investors $\left(G P H_{l t}\right)$ are as follows:

$$
h_{l l t}=M C A P_{l t}-\sum_{k=1}^{43} F P H_{k l t, k \neq l}
$$

where $M C A P_{l t}$ is the market capitalization of equities issued in country $l$ and $F P H_{k l t, k \neq l}$ is the holdings of all equities of country $l$ by foreign investors domiciled in country $k$. The $G P H_{l t}$ is constructed as:

\footnotetext{
${ }^{12}$ In our study the world-market portfolio is the sample 44 countries.
} 


$$
G P H_{l t}=h_{l l t}+\sum_{k=1}^{43} F P H_{l k t, \quad l \neq k}
$$

$F P H_{l k t}$ is the holdings of foreign securities $(k)$ by investors domiciled in country $l$ at time $t$. As the $E H B_{l t}$ is constructed using CPIS data, we denote this variable as CPIS_HB in our empirical analysis.

\subsubsection{Equity foreign bias}

Relative to the ICAPM prediction, equity foreign bias implies the disproportionate allocation of investors domiciled in country $k$ into the foreign securities of countries $l$. Following Chan et al. (2005) we compute the equity foreign bias as:

$$
E F B_{k l t}=\log \left(\frac{W_{k l t}}{W_{l t}^{*}}\right)
$$

where $w_{k l t}$ is the allocation of country $k$ 's investors in equities issued by country $l$ for the period $t$ and is defined as:

$$
w_{k l t}=\frac{h_{k l t}}{\sum_{l=1}^{43} h_{k l t}}
$$

where $h_{k l t}$ denotes country $k$ 's investors' stockholdings of equities in a foreign country $l$ for the period $t . w_{l t}^{*}$, as defined in equation (8), is the ICAPM benchmark allocation for investing in country $l$ for period $t$.

For each pair countries, i.e., $k l$, equity foreign bias could be either positive, where foreign investors' (in country $k$ ) overweight foreign equity market more than that suggested by the implied global weight, or it could be negative, where foreign investors underweight 
their investment away from the implied global weight. ${ }^{13}$ For regression analysis we take the average equity foreign bias $\left(A E F B_{l t}\right)$ exhibited by all source country investors $(k=1 \ldots . . n)$ for the country $l$ for each period $t$ as shown below:

$$
A E F B_{l t}=\frac{\sum_{l=k}^{n} E F B_{k l t}}{n}
$$

Foreign bias measures based on CPIS-IMF and EPFR Global Funds' data are denoted as $C P I S \_F B$ and $G F_{-} F B$ respectively. The number of source countries, i.e. $n$, for $C P I S \_F B$ is 43 (i.e. the same as host countries, excluding the country for which foreign bias is measured, $k \neq l$ ) and the $n$ for the $G F \_F B$, i.e. the number of funds exhibiting foreign bias for each country, is 121 , excluding the fund if its country of domicile is the same as the country of allocation, i.e. $k \neq l$.

\subsection{Control variables}

We use several control variables which could potentially compete with our home and foreign bias measures. Following Kang and Stulz (1997), we use the log of market capitalization (MKTCap) in USD millions to control for the size and information of the market. Hail and Leuz (2006) note that a larger stock market provides more transparent information which could potentially reduce information costs and, hence, lower cost of capital. We expect market capitalization (MKTCap) to be negatively related to cost of capital measures. $C A P M$ predicts a positive association between a firm's beta and risk premium. We compute beta for each market (MSCI country index return) against the MSCI All Country World index return using monthly data for the past five years. The resulting covariance is

\footnotetext{
${ }^{13}$ Note, on aggregate the foreign bias should be negative for each country $(l)$ which exhibits home bias. However, given the fact that CPIS does not report the holding all countries in the world, on average, the foreign bias could be positive or negative. These figures are also reported in the existing literature (see Chan et al. 2005; Lau et al. 2010).
} 
then divided by the variance of MSCI world index return. Following Gebhardt et al. (2001), we use book-to-market ratio $(B M)$ to capture differences in growth opportunities. High $B M$ captures lower growth opportunities, lower accounting conservatism, and high perceived risk. We calculate $B M$ as the $\log$ country level ratio of book-to-market. We construct the total country level book value by aggregating the constituents of each market and scale it by the total market capitalization. The book value figures are from Worldscope.

Consistent with Jegadeesh and Titman (1993), we use the previous year's stock performance $($ Retn_l) to capture the momentum effect on cost of capital. We measure Retn_l as the average MSCI monthly index return over the past year. We further use one-year lagged inflation risk (Infl_l) to control for macroeconomic effect. We control for inflation (Infl_l) to ensure our analysis is not driven by variations in expected inflation rates (Brandt and Wang, 2003 present evidence that equity risk premium is positively related to the inflation rate). We obtain one-year lagged annual inflation rates for each country from WDI. To control for the correlation between exchange return ${ }^{14}$ and equity return, we compute a three-year moving average covariance between the monthly stock market index return and the monthly depreciation of the domestic currency with respect to the dollar. The exchange rates are sourced from Thompson Reuters (see also Adler and Dumas, 1984).

It is well established in the literature that investors demand a liquidity premium for investing in markets with different levels of liquidity (see Gibson and Mougeot, 2004; Bekaert et al. 2006; Chordia et al. 2011). We control for market liquidity using the turnover ratio (Turn) obtained from WDI and World Federation Exchanges (WFE). Earlier studies (Bekaert and Harvey, 1995; Chan et al. 2005) argue that trade openness may drive cost of capital. As such, we further control for market integration (financial and economic) on cost of

\footnotetext{
${ }^{14}$ Exchange rate risk is controlled in the ICRG financial risk measure which includes exchange rate stability sub-component. This sub-component (0-10) measures the appreciation or depreciation of a currency against the US dollar (against the Euro in the case of the USA) over a calendar year or the most recent 12 -month period is calculated as percentage change.
} 
capital by using the log average of a country's annual exports and imports scaled by GDP $(L S M I)$. We also expect that countries with higher economic growth would attract foreign investors, implying global potential risk-sharing owing to growth-reputation, which may reduce cost of capital. We control for economic growth using the real gross domestic product growth $(R G D P G)$ sourced from $W D I$.

La Porta et al. (1998) argue that countries with sound and effective legal systems protect outside investors from expropriation risk. We use the International Country Risk Group $(I C R G)$ rule of law and order $(L a w)$ index (0-6) to capture the variations in the quality and observance of legal rules. We obtain the data from Political Risk Services Group's country risk ratings. Further, studies such as that of Erb et al. (1996), also note that differences in country risk ratings may influence equity returns. Following Erb et al. (1996), we use three broad country risk measures, i.e. political risk (PolRisk), economic policy risk (EconRisk) and financial policy risk (FinRisk) to control for their effect on cost of capital.

The objective of the broad country risk ratings is to provide a common but forward looking variable for assessing the political, economic and financial policy stability in countries covered by ICRG. The political risk rating is rated on a scale of $0-100$ and comprises 12 components. ${ }^{15}$ The economic policy risk is measured on a scale of 0-50 points and incorporates five potential sources of economic risk (GDP per head, real GDP growth, inflation rate, budget balance as a $\%$ of GDP, and current account as a $\%$ of GDP). The financial policy risk measure, which is also measured on a scale of $0-50$, captures five potential sources of financial risk components (foreign debt as a \% of GDP, exchange rate stability, foreign debt as a $\%$ of total export and services, current account as a $\%$ of exports

\footnotetext{
15 The political risk rating captures issues such as government stability, socioeconomic conditions, investment profile, internal conflict, external conflict, corruption, military in politics, religious tension, law and order, ethnic tensions, democratic accountability and bureaucratic quality.
} 
and services, and international liquidity). For all the broad country risk measures, the annual average based on the monthly ratings is used in this study. ${ }^{16}$

We also include the Small-minus-Big $(S M B)$ and High-minus-Low $(H M L)$ measures to control for the size and value effect. For each market, $S M B$ is the difference in annualized average of the monthly returns on the Standard \& Poor's (S\&P) total return index on small and big stocks. Similarly, $H M L$ is the difference in annualized average of the monthly returns on the Standard \& Poor's (S\&P) total return index on growth stocks and value stocks. We obtain country level total return index data from Thompson Reuters.

\section{4. $\quad$ Empirical Analysis}

\subsection{Summary analysis}

Based on MSCI definition, our sample country comprises 23 developed countries and 21 emerging countries from 2001 to 2014. In Panel A of Table 1, we present the sample mean for the various proxies of cost of capital (columns 2-5), ${ }^{17}$ and the international portfolio bias measures are reported in the remaining columns. Matching summary figures are presented in Panel B, for emerging versus developed markets. Finally, Panel C reports the sample average for the top 10 and bottom 10 countries, sorted on the basis of CPIS_HB.

\section{[Insert Table 1 about here]}

Consistent with expectations, the values in Panels A and B show that developed countries exhibit a lower cost of capital relative to their emerging market counterparts. The lowest cost of capital in terms of historical risk premium is observed for Ireland followed by the Ireland, New Zealand, Japan, US, the Netherlands, Switzerland, the UK, Belgium, Hong

\footnotetext{
${ }^{16}$ For further details on the method see ICRG (2012).

${ }^{17}$ We report the summary statistics of the control variables in Appendix 1.
} 
Kong, and Canada. Conversely, the countries ranking with the highest costs of capital are the Brazil, Czech Republic, Egypt, Bulgaria, Thailand, Peru, Indonesia, Poland, Turkey, and Romania. The other three cost of capital proxies show a similar pattern.

In terms of the three alternative measures of sub-optimal portfolio allocations (i.e. CPIS_HB, CPIS_FB and GF_FB) Panels A and B reveal that the top ten countries showing the lowest home bias, i.e. CPIS_HB, are mostly developed countries with the lowest being the US followed by Japan, the UK, Germany, the Netherlands, France, Canada, Ireland, Italy and Hong Kong. Conversely, countries with the strongest home bias are mainly emerging markets; the lowest is Bulgaria, followed by Romania, Peru, Egypt, Hungary, Indonesia, Argentina, Czech Republic, Malaysia, and Philippines. In terms of $C P I S_{-} F B$ (and $G F \_F B$ ), it is unsurprising that European countries predominantly occupy the top ten countries, attributable to being in the same economic union. Nonetheless, we still observe that most developed countries have a stronger positive foreign bias, i.e. these countries mostly preferred by international investors, compared to the emerging markets.

The above analysis clearly indicates that countries with the lowest cost of capital tend to be associated with weaker home bias by their home investors and stronger foreign bias by international investors. Panel $\mathrm{C}$ of Table 1 further supports this view as the lowest home bias for the top ten countries is 2.29 compared to the home bias of the bottom ten countries of 7.15. Comparing this with cost of capital measures, we see that the top ten countries' average $H R R m$ is $8.3 \%$ (with $r C r e d=2.93, C E R P=5 \%$ and $D Y=2.53 \%$ ) compared to the bottom ten $H R R m$ of $24.70 \%$ (with $r C r e d=12.09, C E R P=11.10 \%$ and $D Y=4.04 \%$ ). Similar results are observed when we relate the foreign bias measures $\left(C P I S_{-} F B=0.44\right.$ and $G F_{-} F B=0.02$ for top ten countries) and CPIS_FB $=-1.30$ and $G F \_F B=-2.24$ for bottom ten countries. In conclusion this summary analysis in Table 1 is strongly suggestive that countries with a lower home bias (higher foreign bias) tend to be associated with a lower cost of capital. 


\subsection{Correlation analysis}

Table 2 presents the correlation coefficient matrix between all the variables we use in our analysis. In line with expectations, $C P I S_{-} H B$ is positively and significantly correlated with all of cost of capital measures. This indicates that, from a simple univariate perspective countries with a greater home bias suffer from a higher cost of capital. This is consistent with our summary analysis. Similarly, the CPIS_FB measure is negatively correlated with cost of capital proxies, suggesting that countries which are favoured by foreign investors are associated with a lower cost of capital. Furthermore, the $G F \_F B$ measure also shows negative and statistically significant correlation coefficients, again providing support to the previous findings in Table 1. Most of the other correlation coefficients display expected signs.

\section{[Insert Table 2 about here]}

\subsection{Regression results}

This section examines whether and to what extent the cross-sectional and temporal variations in home biases of domestic investors and foreign biases of foreign investors explain the international variations in cost of capital. To empirically examine this we use pooled OLS regressions using all of our control variables, including year dummies that could potentially be correlated with the different cost of capital measures. All the regression estimations use robust to Newey-West standard errors.

\subsubsection{Cost of capital and equity home bias}

We begin our analysis by assessing the impact of non-optimal domestic allocation, i.e. home bias (CPIS_HB) on cost of capital. In Table 3, we present the regression results showing the relation between equity home bias and four alternative costs of capital proxies. The $t$-statistics are reported in parentheses. In each case the coefficient on CPIS_HB is 
positive and statistically significant, at the $1 \%$ level in models 2 to 4 . Consistent with international risk sharing theory, the results provide compelling evidence that higher home bias is associated with higher cost of capital. Erb et al. (1996) find that an increase of one unit in the log of a country's credit ratings is associated with a reduction of $10 \%$ in cost of equity capital. As we use the same measure of country credit rating (i.e. 1-22), the statistically significant coefficient of 0.235 in Model 2 indicates that a 10 unit increase in the $\log$ of CPIS_HB (i.e. $1 \%$ ) is related to a rise in cost of capital by approximately $0.235^{*} 10=2.35$ basis points.

\section{[Insert Table 3 about here]}

\subsubsection{Cost of capital and equity foreign bias}

Table 4 reports the results of the relation between cost of capital and CPIS_FB. Consistent with expectations, the estimated coefficient on CPIS_FB is negative and statistically significant, at a minimum of $5 \%$ level, in all four regressions. The coefficient of $-0.882(\mathrm{t}$-statistic $=-3.47)$ of Model 1 suggests that the historical risk premium is lower for countries with a higher foreign bias. Model 2 demonstrates a negative coefficient of -0.328 ( $t-$ statistic $=-8.76)$ consistent with the view that favourable country allocation by foreign investors is related to favourable country ratings, indicating a lower cost of capital. Similarly, the coefficient of -0.577 (t-statistic $=-8.61)$ also supports the view that countries which attract higher foreign equity portfolio investments are associated with lower country risk premiums. The results in Model 4 further support the theoretically consistent claim that higher foreign bias is associated with a lower cost of capital.

Model 2 indicates that a 10 unit increase in equity foreign bias is related to a fall in cost of capital by approximately by 3.28 basis points $(-0.328 * 10)$ per year. This is significant because country credit ratings do not move much, as compared to country stock returns. The 
coefficient of -0.395 (t-statistic $=-4.18$ ) also confirms that countries attracting higher allocations are related to lower dividend yield, suggesting a lower cost of capital.

\section{[Insert Table 4 about here]}

\subsubsection{Cost of capital and fund level foreign bias measures}

In Table 5, we replicate the regression of Table 4 by using global fund level data to measure equity foreign bias $\left(G F_{-} F B\right)$. The results show the signs of the coefficients are negative and statistically significant across all the proxies of cost of capital (GF_FB coefficients $-0.874(\mathrm{t}$-statistic $=-4.45),-0.570(\mathrm{t}$-statistic $=-7.56),-0.485(\mathrm{t}$-statistic $=-3.81)$, and -0.307 (t-statistic $=-3.77)$ for HRRm, rCred, CERP, and DY respectively). These results reinforce our previous findings discussed above. This suggests that foreign bias is inversely associated with cost of capital across developed and developing countries. The results imply that the risk sharing benefits of international investments seem to increase as foreign investors tilt their allocations more towards that implied by the ICAPM. This is consistent with the optimal global risk-sharing conjectures of Stulz (1999) and Errunza (2001).

\section{[Insert Table 5 about here]}

\subsubsection{Control variables}

In terms of the control variables, most of them have the expected signs and are statistically significant as reported in Tables 3-5. MKTCap, Retn_1, Infl, Turn, LMSI, $R G D P G$ and Law are negatively and statistically related to HRRm, CERP, rCred and DY. These findings are consistent with existing studies (see Hail and Leuz, 2006). Beta is positively related to cost of capital and statistically significant. Similarly, BM, Exch, PolRisk, EconRisk, FinRisk, SMB and HML are positively associated with cost of capital but their 
statistical significance levels are sensitive to different specifications. Such behaviour of the control variables is also reported by existing studies (see Lau et al. 2010).

\subsection{Robustness tests}

All our empirical results provide strong evidence on the influence of sub-optimal international allocations (i.e. home and foreign biases) on cost of capital, which is consistent with the theory. In this section we run a number of robustness checks to further test the empirical sensitivity of our results. First, we use Tobin's $Q$ as an additional alternative measure of cost of capital. Second, we address the concern of possible endogeneity issues (reverse causality and selection bias) by using two different approaches: firstly we deal with reverse causality using the pre-determined (exogenous) one year lagged values of home and foreign biases and secondly, we use the Heckman selection method to address the sample selection bias.

\subsubsection{Additional measure of cost of capital: Tobin's $Q$.}

In this section we test whether variations in cross-country aggregate firms' valuations can be explained by differences in home and foreign biases. To test the valuation effect and following the existing literature (Chan et al. 2009) we use country level Tobin's $Q$. The country level Tobin's $Q$ measure is constructed by taking the ratio of each country's constituent firms' total liabilities plus equity market value to the book values of the firms' assets. Since there is an inverse relationship between cost of capital and equity market valuation, we expect $C P I S_{-} H B$ (CPIS_FB and $G F_{-} F B$ ) to be negatively (positively) associated with Tobin's $Q$. The results are reported in Table 6.

\section{[Insert Table 6 about here]}


We show in model 1 of Table 6 that the cross-sectional and temporal differences in market valuations are inversely related to $C P I S \_H B$ as demonstrated by the coefficient of $-0.562(\mathrm{t}$-statistic $=-9.60)$. This demonstrates that domestic investors' home bias reduces firm valuations, which in turn implies an increase in cost of capital. This result is consistent with Errunza and Losq (1985) and Stulz (1999). Home bias reduces firm value because local investors bear a large proportion of risk since there is inadequate international risk sharing.

In models 2 and 3 of Table 6 , the results show that both measures of foreign bias (CPIS_FB and $\left.G F_{-} F B\right)$ are associated with higher levels of Tobin's $Q$. The estimated coefficients on $C P I S \_F B$ and $G F \_F B$ of $0.813(\mathrm{t}$-statistic $=5.49)$ in model 2 and $0.448(\mathrm{t}$ statistic $=5.73$ ) in model 3 respectively, implies that as foreign investors increase their allocations towards the suggested ICAPM allocation, firms' value increases, which in turn should reduce cost of capital. As such, using Tobin's $Q$, we further reinforce our previous findings by demonstrating that higher levels of $C P I S_{-} H B\left(C P I S \_F B\right.$ and $\left.G F \_F B\right)$ reduce (increase) equity valuations.

\subsubsection{Reverse causality: Lagged pre-determined variables}

Changes in cost of capital might induce foreign investors to invest more, leading to reduced home bias and increased foreign bias. If this case, our estimates could suffer from endogeneity issues arising from reverse causality. Table 7 provide a summary of the sensitivity analysis. For brevity, we report only the coefficients and t-statistics of the suboptimal portfolio allocation values. Here we address the potential endogeneity problem using one-year lagged values of home and foreign bias as pre-determined exogenous variables.

To address our concern of endogeneity, we use lagged CPIS_HB, CPIS_FB and $G F \_F B$ in our regressions. Consistent with our expectations, all the coefficient estimates on CPIS_HB in Panel A of Table 7 have the expected positive sign and are statistically significant at the $1 \%$ level in all cases. This provides robust support to the results reported in 
Table 5 that higher equity home bias is associated with a higher cost of capital, even after addressing the endogeneity problem arising from potential reverse causality.

\section{[Insert Table 7 about here]}

Similarly, the coefficient estimates on the lagged values of $C P I S_{-} F B$ and $G F \_F B$ reported in Panel B of Table 7 remain negative and statistically significant across all the proxies of cost of capital. Costs of capital measures are statistically significant even at the $1 \%$ level. These results further support our findings that higher equity foreign biases are associated with a lower cost of capital even after controlling for any potential reverse causality issues.

\subsubsection{Dynamic generalized methods of moment estimation}

Despite using the lagged values the estimation could still be subjected to dynamic endogeneity as that past values of our cost of equity may influence the three measures of suboptimal allocation measures. We address this by including the lagged cost of equity as an additional independent variable along with lagged values of all three sub-optimal allocation measures (CPIS_HB, CPIS_FB and $\left.G F_{-} F B\right)$ as predetermined variables and estimate the dynamic generalized methods of moment (GMM) regressions following Arellano and Bond (1991), Arellano and Bover (1995), and Blundell and Bond (1998). The dynamic GMM model takes account of unobservable heterogeneity, simultaneity, and reverses causality (see Beck et al. (2001 Wintoki et al. (2012). The dynamic GMM estimation is appropriate for situation of smaller time waves and larger panels. In our case, the time period is 14 years with 44 panels. Further, the use of lagged value of cost of equity measure takes account for the persistence in cost of equity measure. The dynamic GMM results are reported in Panel B of Table 7. All the estimates again bear the expected signs and support both our hypotheses. 


\subsubsection{Selection bias}

The 44 countries we are able to use are from the 45 all-country index of MSCI and hence, capture $98 \%$ of the highly investable markets. Although we would ideally like to use as many countries as possible, owing to unavailability of data, particularly for smaller emerging and frontier markets, we select 44 countries. In Panel B, we use the standard Heckman selection bias method to address the concern of selection biases which may compromise the validity of the results. The results are reported in Panel $\mathrm{C}$ of Tables 7 for CPIS_HB, CPIS_FB and $G F \_F B$ respectively. The estimated coefficients and statistical significance of all the regressions are qualitatively similar to those reported in previous regressions.

These additional tests demonstrate that our findings are robust to different specifications and use of different estimation methods. The overall results of the empirical analysis provide strong evidence that a higher degree of home bias is related to a higher cost of capital. Correspondingly, foreign investors increasing their portfolio weight towards the global optimum allocations reduces the host country's cost of capital.

\section{Conclusion}

Existing studies provide compelling evidence on the prevalence and persistence of suboptimal international portfolio allocations, leading to the phenomena of home and foreign bias on a global scale. However, the implications of such biases have not been extensively investigated. The theory notes that relative to the ICAPM, as the magnitude of domestic bias in the equity portfolio allocations decreases, it facilitates the benefits of global risk sharing between foreign and domestic investors. Similarly, following the same ICAPM prescription the increase in foreign bias towards a particular host country by foreign investors should also positively influence global risk sharing. 
The increased international diversification of home investors (i.e. decreasing home bias) and foreign investors (i.e. increasing foreign bias) should integrate the host capital market into the world capital market. The benefits of such growing market integration should ultimately manifest itself in the reduction of cost of capital. This suggests that the crosssectional and temporal variations in home and foreign bias should, in part, explain the differences in the cross-country cost of capital. To be specific, home bias (foreign bias) should be associated with a higher (lower) cost of capital. In this study we provide comprehensive, robust and extensive tests of such conjectures.

We use global macro and a unique fund level micro data on 44 cross-countries (developed and emerging) portfolio allocations to construct the home and foreign bias measures. Similarly, following the existing literature we employ five different proxies of cost of capital. Applying robust econometric techniques and a broad spectrum of regression specifications, our study finds that consistent with the theory, countries with higher degree of equity home bias exhibit a higher level of cost of capital. Similarly, higher degrees of foreign bias exhibited by foreign investors in their equity country allocations lower cost of capital for the host countries.

The policy implication of the study indicates that governments, particularly in emerging markets, should initiate reforms for attracting foreign equity investors and encourage domestic investor to diversify internationally. 
Appendix 1

Control variables

\begin{tabular}{|c|c|c|c|c|c|c|c|c|c|c|c|c|c|c|c|}
\hline Country & $\begin{array}{l}\text { MKTCap } \\
\text { (in USD } \\
\text { millions) } \\
\end{array}$ & Beta & $\begin{array}{c}\text { BM } \\
\text { (Ratio) }\end{array}$ & $\underset{(\%)}{\operatorname{Retn} 1}$ & $\begin{array}{c}\text { Exch(Cov.of } \\
\% \text { in } \\
\text { decimals) } \\
\end{array}$ & $\begin{array}{l}\text { Infl } \\
(\%)\end{array}$ & $\begin{array}{l}\text { Turn } \\
(\%)\end{array}$ & $\begin{array}{l}\text { LSMI } \\
\text { (\% of } \\
\text { GDP) } \\
\end{array}$ & $\begin{array}{l}\text { RGDP } \\
(\%)\end{array}$ & $\begin{array}{l}\text { Law } \\
(0-6)\end{array}$ & $\begin{array}{l}\text { PolRisk } \\
(0-100)\end{array}$ & $\begin{array}{c}\text { EconRisk } \\
(0-50)\end{array}$ & $\begin{array}{c}\text { FinRisk } \\
(0-50)\end{array}$ & $\begin{array}{l}\text { SMB } \\
(\%)\end{array}$ & $\begin{array}{c}\text { HML } \\
(\%)\end{array}$ \\
\hline Argentina & 16597.6 & 1.35 & 0.65 & 8.2 & 3.1 & 10.5 & 9.4 & 33.52 & 3.8 & 3.21 & 70.2 & 32.43 & 31.15 & 3.56 & 1.99 \\
\hline Australia & 76437.1 & 0.86 & 0.49 & 5.6 & 0.8 & 2.8 & 85.06 & 41.26 & 2.96 & 5.81 & 87.3 & 29.1 & 36.09 & 4.85 & 0.3 \\
\hline Austria & 55971.06 & 0.83 & 0.58 & 3.8 & 0.2 & 2.1 & 45.73 & 96.34 & 1.41 & 5.85 & 85.1 & 33.65 & 38.43 & 4.91 & -0.69 \\
\hline Belgium & 177872.64 & 0.94 & 0.5 & 1.9 & 0.3 & 2 & 44.12 & 149.03 & 1.3 & 4.7 & 82.1 & 42.97 & 27.78 & 2.57 & 4.55 \\
\hline Brazil & 557517.31 & 2.1 & 1.36 & 16.3 & 1.8 & 6.5 & 34.01 & 25.98 & 3.24 & 2.33 & 66.5 & 34.98 & 32.63 & 12.73 & 4.57 \\
\hline Bulgaria & 50205.06 & 1.33 & 1.44 & 11.2 & 3.8 & 4.8 & 16.46 & 109.77 & 3.3 & 3.89 & 74.6 & 31.08 & 32.3 & 5.94 & 1.52 \\
\hline Canada & 1062678.2 & 0.97 & 0.29 & 5.4 & 1.1 & 1.9 & 74.21 & 66.91 & 20.4 & 5.85 & 85.6 & 41.84 & 29.5 & 8.93 & 0.27 \\
\hline Chile & 103693 & 1.05 & 0.98 & 12.6 & 1.5 & 3.7 & 15.69 & 68.95 & 4 & 4.85 & 76.5 & 40.14 & 25.74 & 3.54 & -0.09 \\
\hline China & 852176.43 & 1.27 & 1.08 & 11.8 & 1.7 & 2.4 & 131.5 & 50.82 & 9.82 & 3.93 & 65.4 & 37.37 & 46.5 & 1.16 & 3.76 \\
\hline Czech Rep & 32290.32 & 0.92 & 1.37 & 8.5 & 2 & 2.3 & 56.23 & 124.68 & 2.48 & 5.15 & 80.7 & 36.91 & 31.03 & 9.45 & -6.07 \\
\hline Denmark & 135541.4 & 0.89 & 0.71 & 1.9 & 1.4 & 1.9 & 78.25 & 93.73 & 0.6 & 5.68 & 85.2 & 43.53 & 41.92 & 1.23 & -1.16 \\
\hline Egypt & 2576.38 & 1.08 & 1.35 & 11.4 & 1.9 & 8.6 & 36.16 & 51.51 & 4.06 & 3.92 & 65 & 34.5 & 33.46 & 6.96 & 5.97 \\
\hline Finland & 145078.72 & 1.58 & 0.57 & 7.2 & 0.9 & 1.7 & 117.47 & 76.14 & 1.24 & 5.85 & 91.6 & 45.22 & 37.21 & 13.35 & -2.29 \\
\hline France & 1433148.5 & 1.15 & 0.35 & 1.9 & 0.9 & 1.6 & 96.91 & 54.82 & 1.1 & 4.62 & 76 & 34.92 & 30.69 & 7.42 & -1.46 \\
\hline Germany & 1029900.5 & 1.28 & 0.36 & 2.7 & 4.6 & 1.6 & 136.98 & 74.98 & 1.03 & 4.55 & 82.3 & 36.07 & 26.22 & 5.36 & -1.54 \\
\hline Greece & 60205.06 & 1.58 & 0.86 & 7.3 & 4.2 & 2.6 & 47.92 & 55.58 & -0.01 & 3.55 & 75.3 & 34.77 & 32.76 & 0.59 & -4.68 \\
\hline Hong Kong & 440528.31 & 1.1 & 1.12 & 2.5 & 0.7 & 1.6 & 88.32 & 387.19 & 3.81 & 4.66 & 79.6 & 43.84 & 41.38 & 5.62 & -3.3 \\
\hline Hungary & 20268.97 & 1.27 & 0.63 & 8.6 & 0.9 & 4.8 & 75.92 & 146.06 & 1.87 & 4.3 & 80.9 & 34.87 & 35.64 & -7.84 & 6.39 \\
\hline India & 513995.72 & 1.15 & 0.9 & 10.2 & 1.82 & 7.1 & 105.76 & 43.74 & 7.25 & 3.7 & 57.9 & 33.53 & 37.38 & 11.58 & -9.46 \\
\hline Indonesia & 122670.88 & 1.29 & 1.06 & 7.4 & 1.9 & 7.7 & 49.34 & 54.66 & 5.37 & 2.92 & 55 & 36.83 & 24.54 & -2.51 & 3.25 \\
\hline Ireland & 56974.99 & 0.86 & 0.45 & 7.8 & 0.9 & 2.2 & 42.88 & 162.49 & 2.35 & 5.85 & 85.7 & 41.85 & 35.59 & 11.36 & 1.12 \\
\hline Israel & 80736.18 & 1.12 & 0.98 & 6.7 & 0.9 & 2.1 & 64.17 & 72.24 & 3.36 & 5.15 & 65.8 & 36.16 & 31.27 & 10.29 & -4.11 \\
\hline Italy & 475029.22 & 0.9 & 0.48 & 2.5 & 0.2 & 2.1 & 142.11 & 51.79 & -0.07 & 3.79 & 78.3 & 35.05 & 31.7 & 1.91 & -4.47 \\
\hline Japan & 2840190.1 & 0.66 & 0.95 & 1.4 & -1.4 & 0.1 & 110.46 & 28.24 & 0.77 & 4.85 & 81.2 & 36.28 & 43.47 & 4.55 & -2.85 \\
\hline Korea & 578837.5 & 1.57 & 0.31 & 4.7 & 1.6 & 2.9 & 217.25 & 84.77 & 4.04 & 4.76 & 76.1 & 41.64 & 34.19 & 3.91 & -7.75 \\
\hline Malaysia & 197732.13 & 0.79 & 0.66 & 7.4 & 1.7 & 2.3 & 31.19 & 181.73 & 4.86 & 3.27 & 74.5 & 35.78 & 36.95 & 1.15 & -1.19 \\
\hline
\end{tabular}




\begin{tabular}{|c|c|c|c|c|c|c|c|c|c|c|c|c|c|c|c|}
\hline Mexico & 215203.86 & 1.18 & 1.42 & 5.3 & 1.6 & 4.4 & 24.47 & 57.6 & 2.13 & 3.42 & 73.2 & 38.38 & 38.97 & 3.49 & 8.08 \\
\hline Netherlands & 349412.38 & 1.2 & 0.47 & 2.2 & 0.7 & 2 & 136.07 & 133.14 & 1.01 & 5.9 & 87.5 & 41.93 & 29.08 & 4 & -0.39 \\
\hline New Zealand & 17449.14 & 0.95 & 0.55 & 11.3 & 1.2 & 2.4 & 42.52 & 59.7 & 2.49 & 5.45 & 84.8 & 27.89 & 26.5 & -1.25 & -1.58 \\
\hline Norway & 157211.12 & 1.19 & 1.24 & 5.1 & 1.2 & 1.9 & 107.76 & 69.76 & 1.6 & 5.55 & 84.9 & 44.6 & 44.74 & 0.03 & -1.04 \\
\hline Peru & 30396.33 & 1.23 & 1.12 & 5.4 & 2.7 & 2.6 & 6.74 & 46.71 & 5.48 & 2.75 & 63.6 & 39.06 & 31.58 & 6.46 & -16.67 \\
\hline Philippines & 5486.65 & 1.01 & 1.05 & 9.7 & 1.6 & 4.4 & 18.46 & 82.24 & 5.11 & 2.7 & 67.2 & 29.84 & 35.77 & 7.48 & -1.79 \\
\hline Poland & 81433.35 & 0.87 & 0.8 & 5.8 & 0.8 & 2.7 & 39.71 & 76.85 & 5.58 & 4.45 & 79.6 & 36.48 & 36.19 & 2.1 & -1.72 \\
\hline Portugal & 52159.64 & 0.86 & 0.36 & 4.6 & 0.6 & 2.2 & 60.56 & 68.39 & 0.07 & 5.05 & 81.7 & 34.63 & 34.6 & 1.96 & 4.41 \\
\hline Romania & 20605.71 & 0.78 & 0.65 & 9.2 & 1.7 & 9.8 & 12.76 & 77.72 & 3.74 & 3.75 & 66.7 & 31.71 & 35.21 & 8.84 & 1.82 \\
\hline Russia & 449527.62 & 1.71 & 0.64 & 5.1 & 3.5 & 11 & 67.03 & 54.39 & 4.21 & 4.29 & 68.9 & 37.73 & 43.92 & 13.8 & -3.2 \\
\hline South Africa & 281863.49 & 1.12 & 1.08 & 11.4 & 2.1 & 5.9 & 50.87 & 59.13 & 3.14 & 2.7 & 71.5 & 35.07 & 25.91 & 7.74 & 4.05 \\
\hline Spain & 459605.66 & 0.93 & 0.27 & 6.4 & 0.9 & 2.5 & 156.54 & 55.76 & 1.42 & 4.66 & 77.8 & 38.29 & 36.77 & 1.94 & -0.27 \\
\hline Sweden & 337099.13 & 1.3 & 0.31 & 5.2 & 0.6 & 1.3 & 115.6 & 84.68 & 1.96 & 5.98 & 90.5 & 44.64 & 28.42 & 8.15 & -8.25 \\
\hline Switzerland & 870988.74 & 0.65 & 0.49 & 4.5 & 1 & 0.6 & 95.72 & 108.32 & 1.82 & 4.75 & 86.4 & 44.93 & 45.24 & 2.92 & -1.64 \\
\hline Thailand & 139411.68 & 1.44 & 0.86 & 8.1 & 2.5 & 2.7 & 91.29 & 138.21 & 3.85 & 3.17 & 64.7 & 34.2 & 33.74 & -3.66 & 2.7 \\
\hline Turkey & 118926.03 & 2.28 & 0.53 & 12.6 & 2.2 & 15.7 & 152.27 & 51.69 & 4.14 & 4.5 & 65.9 & 32.59 & 32.02 & -0.53 & 1.73 \\
\hline United Kingdom & 2422145.3 & 0.87 & 0.39 & 4.5 & 0.5 & 2.3 & 137.17 & 56.96 & 1.72 & 5.3 & 83.3 & 34.08 & 24.27 & 5.89 & 2.23 \\
\hline United States & 12494888 & 0.92 & 0.48 & 3.3 & 0.4 & 2.3 & 202.96 & 26.65 & 1.8 & 4.83 & 76.1 & 27.8 & 30.56 & 4.96 & -1.1 \\
\hline
\end{tabular}

MKTCap is the country market capitalization; Beta is the covariance of $M S C I$ country's' world index return over past five years divided by $M S C I$ world index return variance; $B M$ is the log country level ratio of bookto-market; Retn 1 is the average MSCI monthly index return over the past year; Exch is the three year moving average covariance of the monthly stock market index return with the monthly depreciation of the domestic currency with respect to the dollar; Infl is the following year's percentage change in the consumer price index; Turn is the ratio of the total traded volume of stock in a year divided by market capitalization; $L S M I$ is the stock market integration measured as the ratio of a country's annual exports plus imports divided by GDP; RGDPG is the real growth rate in the domestic product; Law represents the rule of law index of a country; PolRisk is the political risk index of a country; EconRisk represents the economic risk index of a country; FinRisk is the financial risk of a country; SMB is return based-factor and is measured as small-stock minus big-stock; $H M L$ is return based-factor and is measured as high-book-to-market minus low-book-to-market. 


\section{References}

Adler, M., Dumas, B., 1983. International portfolio selection and corporate finance: a synthesis. Journal of Finance. 46, 925-984.

Adler, M., Dumas, B., 1984. Exposure to currency risk: definition and measurement. Financial Management. 13, 41-50.

Ahearne, A., Griever, W., Warnock, F., 2004. Information costs and home bias: an analysis of US holdings of foreign equities. Journal of International Economics. 62, 313-336.

Arellano, M., Bond, S., 1991. Some tests of specification for panel data: Monte Carlo evidence and an application to employment equations. The Review of Economic Studies. $58,277-297$.

Arellano, M., Bover, O., 1995. Another look at the instrumental variable estimation of errorcomponent models. Journal of Economics. 68, 29-51.

Beck, T., Clarke, G., Groff, A., Keefer, P., Walsh, P., 2001. Tools in comparative political economy: the database of political institutions. World Bank Economic Review. 15, 165 176.

Bekaert, G., Harvey, C.R., 1995. Time-varying world market integration. Journal of Finance. $50,403-444$.

Bekaert, G., Harvey, C.R., 2000. Foreign speculators and emerging equity markets. Journal of Finance. 55, 565-613.

Bekaert, G., Harvey, C.R., 2003. Emerging markets finance. Journal of Empirical Finance. $10,3-55$.

Bekaert, G., Harvey, C.R., 2005. Chronology of important economic, financial and political events in emerging markets, http://www.duke.edu/ charvey/chronology.htm.

Bekaert, G., Harvey, C.R., Lundblad, C.T., 2006. Growth volatility and financial liberalization. Journal of International Money and Finance. 25, 370-403.

Bekaert, G., Wang, X., 2010. Inflation risk and the inflation premium. Economic policy. 25, 755-806.

Bekaert, G., Harvey C., Lundblad C., Siegel S., 2011. What segments equity markets? Review of Financial Studies. 12, 3841-3890.

Bhattacharya, U., Daouk, H., 2002. The world price of insider trading. Journal of Finance. 57, 75-108.

Blundell, R., Bond, S., 1998. Initial conditions and moment restrictions in dynamic panel data models. Journal of Economics. 87, 115-143.

Brandt, M.W., Wang, K.Q., 2003. Time-varying risk aversion and unexpected inflation, Journal of Monetary Economics. 50, 1457-1498. 
Carrieri, F., Chaieb I., Errunza V., 2013. Do implicit barriers matter for globalization? Review of Financial Studies. 26, 1694-1739.

Chaieb, I., Errunza V., 2007. International asset pricing under segmentation and PPP deviations, Journal of Financial Economics. 86, 543-578.

Chan, K., Covrig, V., Ng, L., 2005. What determines the domestic bias and foreign bias? Evidence from mutual fund equity allocations world- wide. Journal of Finance. 60, 14951534.

Chan, K., Covrig, V., Ng, L., 2009. Does home bias affect firm value? Evidence from holdings of mutual funds worldwide. Journal of International Economics. 78, 230-241.

Chari, A., Henry, P., 2004. Risk sharing and asset prices: Evidence from a natural experiment. Journal of Finance. 59, 1295-1324.

Chordia, T., Roll, R., Subrahmanyam, A., 2011. Recent trends in trading activity and market quality. Journal of Financial Economics. 101, 243-263.

Dahlquist, M., Pinkowitz, L., Stulz, R., Williamson, R., 2003. Corporate governance, investor protection, and home bias. Journal of Financial and Quantitative Analysis. 38, 87-110.

Damodaran, A., 2012. Equity risk premium (ERP): Determinants, estimation and implications. 2012 Edition (http://papers.ssrn.com/sol3/papers.cfm?abstract_id=2027211

De Jong, F., de Roon, F., 2005. Time-varying market integration and expected returns in emerging markets. Journal of Financial Economics. 78, 583-613.

Edison, H.J., Warnock, F.E., 2008. Cross-border listings, capital controls, and equity flows to emerging markets. Journal of International Money and Finance. 27, 1013-27.

Erb, C., Harvey, C.R., Viskanta, T., 1996. Expected returns and volatility in 135 countries. Journal of Portfolio Management. 22, 46-58.

Errunza, V., 2001. Foreign portfolio equity investments, financial liberalization, and economic development. Review of International Economics. 9, 703-726.

Errunza, V., Losq, E., 1985. International asset pricing and mild segmentation: Theory and test. Journal of Finance. 40, 105-124.

Errunza, V., Miller, D.P., 2000. Market segmentation and the cost of capital in international equity markets. Journal of Financial and Quantitative Analysis. 35, 577-600.

Fidora, M., Fratzscher, M., Thimann, C., 2007. Home bias in global bond and equity markets; The role of real exchange rate volatility. Journal of International Money and Finance. 26, 631-655.

Foerster, S., Karolyi, G.A., 1999. The effects of market segmentation and investor recognition on asset prices: evidence from foreign stocks listing in the United States. Journal of Finance. 54, 981-1014. 
Gebhardt, W.R., Lee, C.M., Swaminathan, B., 2001. Toward an implied cost of capital. Journal of Accounting Research. 39, 135-176.

Gelos, R.G., Wei, S.J., 2005. Transparency and international portfolio holdings. Journal of Finance. 60, 2987-3020.

Gibson, R., Mougeot, N., 2004. The pricing of systematic liquidity risk: Empirical evidence from the US stock market. Journal of Banking and Finance. 28, 157-178.

Hail, L., Leuz, C., 2006. International differences in cost of equity capital: do legal institutions and securities regulation matter? Journal of Accounting Research. 44, 485531.

Hail, L., Leuz, C., 2009. Cost of capital and changes in growth expectations around U.S cross-listings. Journal of Financial Economics. 93, 428-454.

Henry, P.B., 2000. Stock market liberalization, economic reform and emerging market equity prices. Journal of Finance. 55, 529-564.

International Country Risk Guide. 2012. [Online] Available from: http://www.eui.eu/Research/Library/ElectronicResources/E-Resources/2012/12-10InternationalCountryRiskGuide.aspx [Accessed 15 November 2012].

Jegadeesh, N., Titman, S., 1993. Returns to buying winners and selling losers: Implications for stock market efficiency. Journal of Finance. 48, 65-91.

Jewel, J., Livingston, M., 1998. Split ratings, bond yields, and underwriter spreads. Journal of Financial Research. 21, 185-204.

Jotikasthira, C., Lundblad, C., Ramadorai, T., 2012. Asset fire sales and purchases and the international transmission of funding shocks. Journal of Finance. 67, 2015-2050

Kang, J.K., Stulz, R.M., 1997. Why is there a home bias? An analysis of foreign portfolio equity ownership in Japan. Journal of Financial Economics. 46, 3-28.

Karolyi, A., 2004. The role of ADRs in the development of emerging equity markets. Review of Economics and Statistics. 86, 670-690.

Kim, E.H., Singal, V., 2000. Stock market openings: experience of emerging economies. Journal of Business. 73, 25-66.

Kim, H., Cho., S.H., Kim, Y., 2015. Home bias, risk differential, and cultural spatial spill over effects. Journal of International Money and Finance. 51, 114-136.

La Porta, R., Vishny, R., Lopez-De-Silanes, F., Shleifer, A., 1998. Law and finance. Journal of Political Economics. 106, 1113-1155.

Lau, S.T., Ng, L., Zhang, B., 2010. The world price of home bias. Journal of Financial Economics. 97, 191-217. 
Lewis, K., 1999. Explaining home bias in equities and consumption. Journal of Economic Literature. 37, 571-608.

Mishra, A.V., 2014. Austria's home bias and cross border taxation. Global Finance Journal. $25,108-123$.

O’Hagan-Luff, M., Berrill, J., 2015. Why stay-at-home investing makes sense. International Review of Financial Analysis. 38, 1-14.

Reeb, D.M., Sattar, A.M., Alle, J.M., 2001. Firm internationalization and the cost of debt financing. Evidence from non-provisional publicly traded debt. The Journal of Financial and Quantitative Analysis. 36, 395-414.

Solnik, B., 1974. An equilibrium model of the international capital market. Journal of Economic Theory. 8, 500-524.

Stulz, R.M., 1999. Globalization, corporate finance, and the cost of equity capital. Journal of Applied Corporate Finance. 12, 8-25.

Wintoki, M.B., Linck, J.S., Netter, J.M., 2012. Endogeneity and the dynamics of internal corporate governance. Journal of Financial Economics. 105, 581-606. 
Table 1

Summary statistics of dependent and key independent variables

\begin{tabular}{|c|c|c|c|c|c|c|c|}
\hline Country & $\begin{array}{c}\text { HRRm } \\
(\%)\end{array}$ & $\begin{array}{l}\text { rCred } \\
(1-22)\end{array}$ & $\begin{array}{c}\text { CERP } \\
(\%)\end{array}$ & $\begin{array}{c}\text { DY (\% of } \\
\text { price) }\end{array}$ & CPIS_HB & CPIS_FB & GF_FB \\
\hline Argentina & 23 & 16.6 & 16 & 3.44 & 6.60 & -0.53 & -2.36 \\
\hline Australia & 12 & 2.8 & 7 & 3.20 & 3.40 & -0.19 & -0.44 \\
\hline Austria & 11 & 2.7 & 8 & 1.88 & 4.18 & 0.89 & -0.48 \\
\hline Belgium & 9 & 2.6 & 7 & 2.34 & 3.30 & 0.74 & -0.49 \\
\hline Brazil & 33 & 14.2 & 13 & 4.56 & 5.34 & -2.37 & -1.22 \\
\hline Bulgaria & 29 & 14.7 & 11 & 3.27 & 9.59 & -2.11 & -2.56 \\
\hline Canada & 10 & 2.1 & 4 & 2.11 & 2.81 & -0.07 & -0.64 \\
\hline Chile & 20 & 5.4 & 8 & 4.74 & 5.33 & -0.24 & -2.88 \\
\hline China & 13 & 8.3 & 9 & 3.68 & 3.15 & -2.13 & -1.37 \\
\hline Czech Republic & 30 & 7.2 & 7 & 4.53 & 6.40 & 0.09 & -1.96 \\
\hline Denmark & 13 & 2.5 & 4 & 1.23 & 4.22 & 0.46 & -0.43 \\
\hline Egypt & 29 & 11.6 & 7 & 5.42 & 7.27 & -1.02 & -3.28 \\
\hline Finland & 17 & 2.0 & 6 & 2.73 & 4.15 & 0.34 & 0.26 \\
\hline France & 11 & 2.0 & 6 & 2.57 & 2.62 & 0.44 & 0.13 \\
\hline Germany & 15 & 2.0 & 5 & 2.34 & 2.19 & 0.55 & 0.08 \\
\hline Greece & 17 & 9.3 & 9 & 5.26 & 4.72 & 0.18 & -0.85 \\
\hline Hong Kong & 9 & 5.7 & 7 & 3.45 & 2.87 & 0.17 & 0.87 \\
\hline Hungary & 19 & 6.8 & 7 & 3.66 & 6.98 & -0.44 & -1.75 \\
\hline India & 21 & 13.4 & 12 & 3.28 & 4.76 & -4.79 & -2.42 \\
\hline Indonesia & 26 & 15.1 & 15 & 3.77 & 6.95 & -1.31 & -2.18 \\
\hline Ireland & 5 & 2.2 & 4 & 2.35 & 2.84 & 1.53 & -0.35 \\
\hline Israel & 13 & 5.8 & 5 & 2.94 & 4.68 & -0.28 & -0.27 \\
\hline Italy & 11 & 3.6 & 5 & 3.15 & 2.84 & 0.58 & -0.06 \\
\hline Japan & 5 & 5.7 & 7 & 1.75 & 1.70 & 0.21 & -0.14 \\
\hline Korea & 14 & 7.9 & 9 & 2.08 & 4.56 & -0.72 & -0.26 \\
\hline Malaysia & 19 & 8.8 & 10 & 4.28 & 6.21 & -1.06 & -2.73 \\
\hline Mexico & 17 & 10.5 & 11 & 2.97 & 5.35 & -1.93 & -1.24 \\
\hline Netherlands & 6 & 2.0 & 4 & 3.65 & 2.31 & 0.66 & 0.20 \\
\hline New Zealand & 5 & 2.2 & 4 & 3.55 & 5.77 & 0.18 & 0.84 \\
\hline Norway & 13 & 2.0 & 5 & 2.47 & 3.87 & 0.70 & -0.14 \\
\hline Peru & 26 & 12.4 & 12 & 4.36 & 7.63 & -0.60 & -2.32 \\
\hline Philippines & 23 & 13.1 & 13 & 3.93 & 6.20 & -3.81 & -1.61 \\
\hline Poland & 25 & 6.8 & 9 & 3.68 & 5.97 & -0.71 & -3.27 \\
\hline Portugal & 12 & 5.2 & 7 & 3.24 & 5.28 & 0.60 & -0.14 \\
\hline Romania & 23 & 14.6 & 13 & 3.71 & 7.64 & -2.17 & -1.68 \\
\hline Russia & 14 & 12.8 & 14 & 3.47 & 4.90 & -3.46 & -3.16 \\
\hline South Africa & 19 & 8.6 & 11 & 4.20 & 4.78 & -0.48 & -2.65 \\
\hline Spain & 14 & 2.2 & 6 & 2.83 & 3.09 & 0.04 & -0.43 \\
\hline Sweden & 10 & 2.2 & 5 & 2.30 & 3.75 & 0.27 & 0.09 \\
\hline Switzerland & 6 & 2.0 & 4 & 1.64 & 3.11 & 0.33 & 0.13 \\
\hline Thailand & 26 & 10.2 & 12 & 4.21 & 5.83 & -0.96 & -1.68 \\
\hline Turkey & 24 & 16.3 & 15 & 2.83 & 5.44 & -3.64 & -2.53 \\
\hline United Kingdom & 6 & 2.0 & 4 & 2.42 & 2.03 & 0.35 & 0.26 \\
\hline United States & 5 & 2.0 & 4 & 1.54 & 0.65 & -0.07 & -0.13 \\
\hline
\end{tabular}


Table 1 cont.

Panel B: Averages of the developed and emerging countries.

\begin{tabular}{lccccccc}
\hline Country & $\begin{array}{c}\text { HRRm } \\
(\%)\end{array}$ & $\begin{array}{c}\text { rCred } \\
(1-22)\end{array}$ & $\begin{array}{c}\text { CERP } \\
(\%)\end{array}$ & $\begin{array}{c}\text { DY }(\% \\
\text { of price })\end{array}$ & CPIS_HB & CPIS_FB & GF_FB \\
\hline Developed & 10.21 & 3.17 & 5.52 & 2.65 & 3.32 & 0.37 & -0.09 \\
Emerging & 22.52 & 11.21 & 11.14 & 3.81 & 6.04 & -1.05 & -2.15 \\
\hline
\end{tabular}

Panel C: Averages of the top and bottom 10 countries.

\begin{tabular}{lccccccc}
\hline Country & $\begin{array}{c}\text { HRRm } \\
(\%)\end{array}$ & $\begin{array}{c}\text { rCred } \\
(1-22)\end{array}$ & $\begin{array}{c}\text { CERP } \\
(\%)\end{array}$ & $\begin{array}{c}\text { DY (\% } \\
\text { of price })\end{array}$ & CPIS_HB & CPIS_FB GF_FB \\
\hline Top10 & 8.3 & 2.93 & 5 & 2.53 & 2.29 & 0.44 & 0.02 \\
Bottom10 & 24.7 & 12.09 & 11.10 & 4.04 & 7.15 & -1.30 & -2.24 \\
\hline
\end{tabular}

Note: The variables in columns 2-5 are cost of capital measures. HRRm is the historical realized market return measured as the historical average of excess country equity market return over risk free rate. $r$ Cred is the natural log of numerical values based on Moody's country credit ratings. The qualitative credit ratings are converted into numerical values based on a scale of 1-22. We assigned a value of 1 to $A A A=1, A A+=2, A A=3 \ldots$ all the way to $D=22$. CERP is the country equity risk premium based on adding the sovereign default risk premium (scaled by the relative volatility of equity to bond market) to the equity risk premium of a base country (The United States). DY is the dividend yield measured as the total amount of stock dividend of a country as a percentage of the market capitalization of the country. The variables listed in columns 6-8 are the sub-optimal international portfolio allocation bias measures. CPIS_HB is the IMF-CPIS based equity home bias and is calculated as the log value of the share of domestic investors in their own country's stock market capitalization $(l)$ relative to the country's world market capitalization weight. CPIS_FB is the IMF-CPIS based equity foreign bias measure computed as the average of the log value of the ratio of foreign allocations from foreign investors domiciled in country $k$ investing in equities of country $l$ to the benchmark allocation for country $l(k \neq l)$. GF_FB is also an equity foreign bias measure but constructed using EPFR's global micro fund level data. 
Table 2

Pearson's pairwise correlation coefficient between the dependent and independent variables

\begin{tabular}{|c|c|c|c|c|c|c|c|c|c|c|c|c|c|c|c|c|c|c|c|c|c|c|}
\hline & 1 & 2 & 3 & 4 & 5 & 6 & 7 & 8 & 9 & 10 & 11 & 12 & 13 & 14 & 15 & 16 & 17 & 18 & 19 & 20 & 21 & 22 \\
\hline HRRm (1) & 1 & & & & & & & & & & & & & & & & & & & & & \\
\hline rCred (2) & $0.49 *$ & 1 & & & & & & & & & & & & & & & & & & & & \\
\hline CERP (3) & $0.52^{*}$ & $0.66^{*}$ & 1 & & & & & & & & & & & & & & & & & & & \\
\hline DY (4) & $0.14 *$ & 0.25 & $0.10^{*}$ & 1 & & & & & & & & & & & & & & & & & & \\
\hline CPIS_HB (5) & $0.16^{*}$ & $0.55^{*}$ & $0.44 *$ & $0.12^{*}$ & 1 & & & & & & & & & & & & & & & & & \\
\hline CPIS_FB (6) & -0.25 & $-0.58^{*}$ & $-0.53^{*}$ & -0.15 & -0.41 & 1 & & & & & & & & & & & & & & & & \\
\hline GF_FB (7) & -0.12 & $-0.45^{*}$ & -0.35 & -0.07 & -0.44 & $0.50^{*}$ & 1 & & & & & & & & & & & & & & & \\
\hline MKTCap (8) & $-0.38^{*}$ & -0.05 & -0.05 & $-0.25^{*}$ & -0.22 & $-0.16^{*}$ & 0.06 & 1 & & & & & & & & & & & & & & \\
\hline Beta (9) & $0.29 *$ & $0.26^{*}$ & $0.23^{*}$ & 0.07 & 0.08 & -0.19 & 0.05 & 0.07 & 1 & & & & & & & & & & & & & \\
\hline BM (10) & $0.18^{*}$ & $0.23^{*}$ & $0.20^{*}$ & 0.05 & $0.37^{*}$ & -0.27 & $-0.11^{*}$ & 0.06 & 0.06 & 1 & & & & & & & & & & & & \\
\hline Retn_1 (11) & $0.08^{*}$ & $0.24 *$ & $0.24 *$ & $0.15^{*}$ & $0.29 *$ & -0.24 & $-0.19^{*}$ & -0.05 & 0.31 & 0.23 & 1 & & & & & & & & & & & \\
\hline Exch (12) & $0.16^{*}$ & $0.08^{*}$ & 0.09 & 0.10 & 0.06 & -0.12 & $-0.15^{*}$ & 0.06 & 0.04 & -0.13 & $-0.35^{*}$ & 1 & & & & & & & & & & \\
\hline $\operatorname{Infl}(13)$ & $-0.22^{*}$ & $-0.38^{*}$ & $-0.28^{*}$ & -0.05 & $0.27^{*}$ & -0.30 & $-0.27^{*}$ & -0.03 & $0.18^{*}$ & 0.05 & $0.22^{*}$ & $0.23^{*}$ & 1 & & & & & & & & & \\
\hline Turn (14) & $-0.18^{*}$ & $-0.50^{*}$ & $-0.40^{*}$ & -0.16 & -0.64 & $0.19^{*}$ & $0.43^{*}$ & $0.33^{*}$ & $0.21 *$ & $-0.33^{*}$ & 0.05 & -0.07 & -0.23 & 1 & & & & & & & & \\
\hline LSMI (15) & $-0.13^{*}$ & $-0.22^{*}$ & $-0.24 *$ & -0.11 & $0.13^{*}$ & $0.30^{*}$ & 0.08 & -0.20 & -0.13 & 0.04 & -0.04 & -0.05 & -0.09 & -0.05 & 1 & & & & & & & \\
\hline RGDPG (16) & $-0.14 *$ & -0.29 & $-0.29 *$ & -0.14 & $0.21^{*}$ & $-0.45^{*}$ & -0.25 & -0.05 & 0.09 & -0.06 & -0.07 & $0.28^{*}$ & $0.15^{*}$ & -0.06 & -0.04 & 1 & & & & & & \\
\hline Law (17) & $-0.34^{*}$ & $-0.58^{*}$ & $-0.46^{*}$ & -0.06 & $-0.35^{*}$ & $0.58^{*}$ & $0.37^{*}$ & -0.06 & -0.13 & -0.29 & $-0.24^{*}$ & -0.04 & -0.31 & $0.40^{*}$ & $0.21^{*}$ & -0.23 & 1 & & & & & \\
\hline PolRisk (18) & $0.27 *$ & $0.64^{*}$ & $0.47 *$ & 0.07 & $-0.37^{*}$ & $0.70^{*}$ & $0.37^{*}$ & -0.11 & -0.15 & -0.31 & -0.33 & -0.08 & -0.39 & $0.28^{*}$ & $0.27 *$ & -0.27 & $0.73^{*}$ & 1 & & & & \\
\hline EconRisk (19) & 0.08 & $0.29^{*}$ & $0.23^{*}$ & 0.04 & -0.15 & $0.23^{*}$ & $0.22^{*}$ & $0.12^{*}$ & 0.06 & -0.04 & -0.05 & 0.04 & -0.13 & $0.18^{*}$ & $0.28^{*}$ & -0.06 & $0.21^{*}$ & $0.26^{*}$ & 1 & & & \\
\hline FinRisk (20) & $0.11^{*}$ & 0.07 & 0.08 & 0.20 & -0.08 & 0.11 & 0.09 & -0.05 & -0.11 & $0.13^{*}$ & -0.10 & 0.05 & -0.12 & 0.05 & 0.06 & 0.12 & 0.11 & 0.11 & 0.09 & 1 & & \\
\hline SMB (21) & $0.14^{*}$ & $0.21^{*}$ & $0.33^{*}$ & $0.25^{*}$ & -0.47 & $0.13^{*}$ & $0.16^{*}$ & $-0.12^{*}$ & -0.03 & $0.11^{*}$ & $0.09^{*}$ & -0.19 & -0.14 & -0.08 & -0.15 & -0.28 & $0.06^{*}$ & $0.04 *$ & $0.08^{*}$ & $0.11^{*}$ & 1 & \\
\hline HML (22) & $0.12^{*}$ & $0.18^{*}$ & $0.26^{*}$ & $0.23 *$ & $-0.51^{*}$ & $0.29 *$ & 0.18 & -0.05 & 0.09 & 0.07 & $0.06^{*}$ & -0.32 & $0.21^{*}$ & $0.11^{*}$ & $0.08^{*}$ & -0.17 & 0.05 & 0.03 & 0.05 & 0.10 & $0.17^{*}$ & 1 \\
\hline
\end{tabular}

Note: The variables labelled 1- 4 are cost of capital measures and 5-7 are the sub-optimal international portfolio allocation bias measures. They are described in Table 1. The other variables include MKTCap as the log country market capitalization; $B e t a$ is the covariance of $M S C I$ all country's world index return over the past five years divided by the $M S C I$ world index return variance; $B M$ is the log country level ratio of book-to-market; Retn 1 is the average $M S C I$ monthly index return over the past year; Exch is the three year moving average covariance of the monthly stock market index return with the monthly change of the domestic currency with respect to the dollar; Infl is the one year lagged rate of inflation based on the consumer price index; Turn is the ratio of the total traded volume of stock in a year divided by market capitalization; $L S M I$ is a measure of market integration measured as the ratio of a country's annual exports plus imports divided by GDP; $R G D P G$ is the real growth rate in the domestic product; Law represents the rule of law rating index of a country; PolRisk is the political risk rating index of a country; EconRisk represents the economic risk rating index of a country; FinRisk is the financial risk rating index of a country; SMB is return based-factor and is measured as small-stock minus big-stock; $H M L$ is return based-factor and is measured as high-book-to-market minus low-book-to-market. Statistical significance is reported against $10 \%(*), 5 \%$ $(* *)$ and $1 \%(* * *)$ 
Table 3

The relation between equity home bias and the four cost of capital proxies

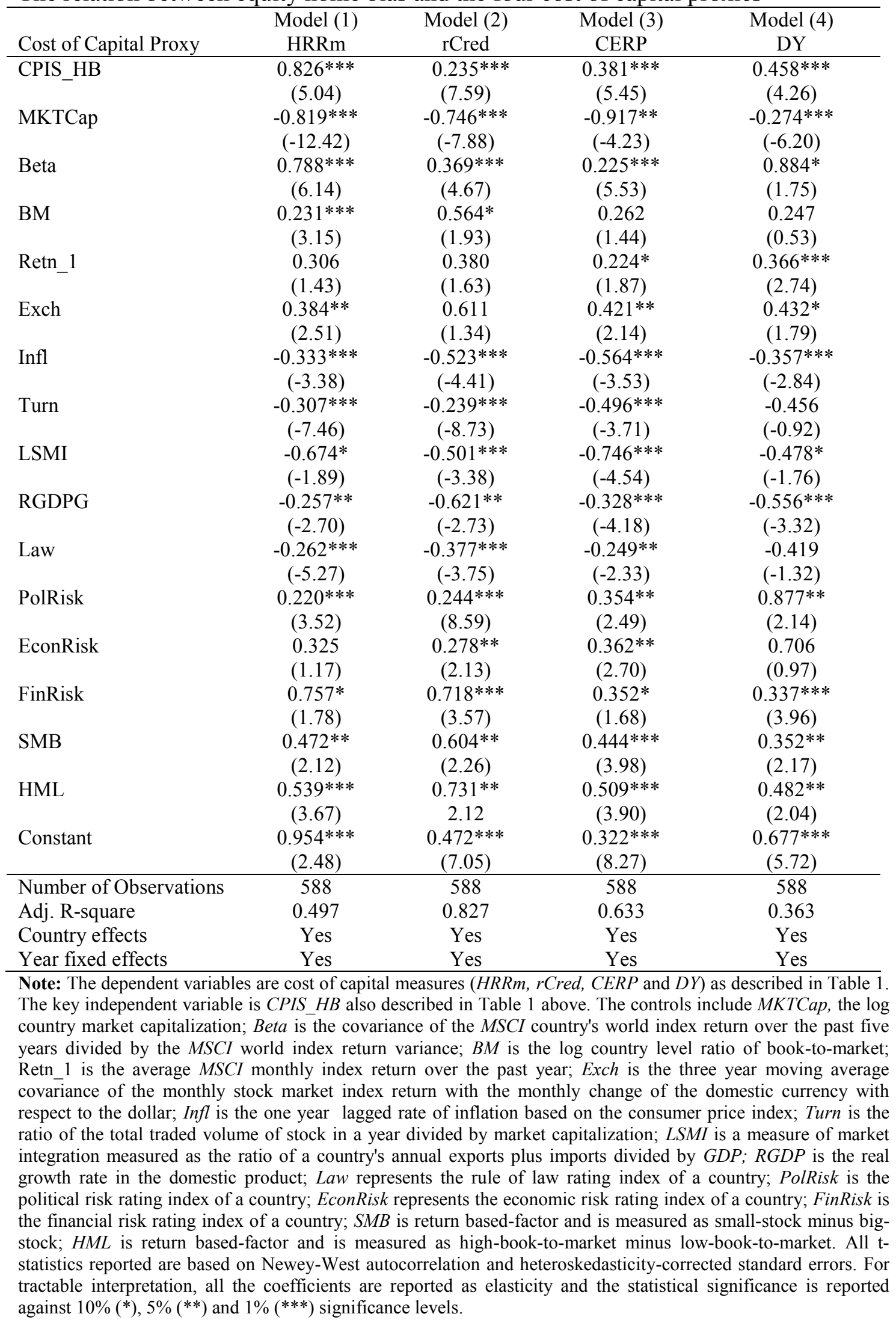


Table 4

The relation between equity foreign bias and the four cost of capital proxies

\begin{tabular}{|c|c|c|c|c|}
\hline Cost of capital proxy & $\begin{array}{c}\text { Model (1) } \\
\text { HRRm }\end{array}$ & $\begin{array}{c}\text { Model (2) } \\
\text { rCred }\end{array}$ & $\begin{array}{c}\text { Model (3) } \\
\text { CERP }\end{array}$ & $\begin{array}{c}\text { Model (4) } \\
\text { DY }\end{array}$ \\
\hline CPIS_FB & $\begin{array}{c}-0.882 * * * \\
(-3.47)\end{array}$ & $\begin{array}{c}-0.328 * * * \\
(-8.76)\end{array}$ & $\begin{array}{c}-0.577 * * * \\
(-8.61)\end{array}$ & $\begin{array}{c}-0.395 * * * \\
(-4.18)\end{array}$ \\
\hline MKTCap & $\begin{array}{c}-0.426^{* * *} \\
(-3.58)\end{array}$ & $\begin{array}{c}-0.980 * * * \\
(-3.83)\end{array}$ & $\begin{array}{c}-0.496^{* * *} \\
(-3.83)\end{array}$ & $\begin{array}{c}-0.580 * * * \\
(-6.46)\end{array}$ \\
\hline Beta & $\begin{array}{c}0.747^{*} \\
(1.90)\end{array}$ & $\begin{array}{c}0.957 * * * \\
(7.61)\end{array}$ & $\begin{array}{c}0.575 * * * \\
(4.47)\end{array}$ & $\begin{array}{c}0.432 * * \\
(2.21)\end{array}$ \\
\hline $\mathrm{BM}$ & $\begin{array}{l}0.498 \\
(0.23)\end{array}$ & $\begin{array}{l}0.262 \\
(0.80)\end{array}$ & $\begin{array}{c}0.296^{*} \\
(1.74)\end{array}$ & $\begin{array}{c}0.543^{*} \\
(1.77)\end{array}$ \\
\hline Retn_1 & $\begin{array}{c}-0.375 * * \\
(-2.13)\end{array}$ & $\begin{array}{c}-0.234 * \\
(-1.85)\end{array}$ & $\begin{array}{c}-0.239 * * * \\
(-3.58)\end{array}$ & $\begin{array}{c}-0.365 * * * \\
(-3.92)\end{array}$ \\
\hline Exch & $\begin{array}{l}0.314 \\
(1.08)\end{array}$ & $\begin{array}{l}0.422 \\
(1.14)\end{array}$ & $\begin{array}{c}0.587 * * * \\
(3.54)\end{array}$ & $\begin{array}{l}0.548 \\
(1.26)\end{array}$ \\
\hline Infl & $\begin{array}{c}-0.720 * * * \\
(-3.65)\end{array}$ & $\begin{array}{c}-0.864 * * * \\
(-4.76)\end{array}$ & $\begin{array}{c}-0.452 * * * \\
(-3.76)\end{array}$ & $\begin{array}{c}-0.423 * * \\
(-2.17)\end{array}$ \\
\hline Turn & $\begin{array}{c}-0.929^{*} \\
(-1.83)\end{array}$ & $\begin{array}{c}-0.430 * * * \\
(-11.87)\end{array}$ & $\begin{array}{c}-0.530 * * * \\
(-7.22)\end{array}$ & $\begin{array}{c}-0.376^{*} \\
(-1.69)\end{array}$ \\
\hline LSMI & $\begin{array}{l}-0.663 \\
(-0.77)\end{array}$ & $\begin{array}{l}-0.429 \\
(-0.91)\end{array}$ & $\begin{array}{l}-0.563 \\
(-0.69)\end{array}$ & $\begin{array}{c}-0.994 * * \\
(-2.18)\end{array}$ \\
\hline RGDPG & $\begin{array}{c}-0.334 * * * \\
(-3.67)\end{array}$ & $\begin{array}{c}-0.517 * * \\
(-2.28)\end{array}$ & $\begin{array}{c}-0.562 * * * \\
(-3.60)\end{array}$ & $\begin{array}{c}-0.625 * * * \\
(-3.14)\end{array}$ \\
\hline Law & $\begin{array}{c}-0.246^{* * *} \\
(-4.53)\end{array}$ & $\begin{array}{c}-0.349 * * \\
(-2.73)\end{array}$ & $\begin{array}{l}-0.484 \\
(-1.28)\end{array}$ & $\begin{array}{c}-0.351^{* *} \\
(-2.37)\end{array}$ \\
\hline PolRisk & $\begin{array}{c}0.215^{* * *} \\
(4.08)\end{array}$ & $\begin{array}{c}0.196 * * * \\
(6.69)\end{array}$ & $\begin{array}{c}0.207^{*} \\
(1.86)\end{array}$ & $\begin{array}{c}0.433 * * \\
(2.30)\end{array}$ \\
\hline EconRisk & $\begin{array}{c}0.251 * * \\
(2.59)\end{array}$ & $\begin{array}{c}0.540 * * * \\
(4.64)\end{array}$ & $\begin{array}{c}0.988 * * \\
(2.79)\end{array}$ & $\begin{array}{c}0.265 * * \\
(2.58)\end{array}$ \\
\hline FinRisk & $\begin{array}{c}0.411 * * \\
(2.30)\end{array}$ & $\begin{array}{l}0.228 \\
(0.67)\end{array}$ & $\begin{array}{c}0.257 * * * \\
(3.98)\end{array}$ & $\begin{array}{l}0.124 \\
(1.57)\end{array}$ \\
\hline SMB & $\begin{array}{c}0.207 * * \\
(2.75)\end{array}$ & $\begin{array}{c}0.448^{* *} \\
(2.18)\end{array}$ & $\begin{array}{c}0.379 * * * \\
(3.52)\end{array}$ & $\begin{array}{c}0.272 * * \\
(2.03)\end{array}$ \\
\hline HML & $\begin{array}{c}0.523 * * * \\
(3.04)\end{array}$ & $\begin{array}{c}0.396 * * \\
(2.67)\end{array}$ & $\begin{array}{c}0.219 * * * \\
(3.16)\end{array}$ & $\begin{array}{c}0.282 * * \\
(2.35)\end{array}$ \\
\hline Constant & $\begin{array}{c}0.242 * * * \\
(3.83)\end{array}$ & $\begin{array}{c}0.423 * * * \\
(11.38)\end{array}$ & $\begin{array}{c}0.863 * * * \\
(11.43)\end{array}$ & $\begin{array}{c}0.771 * * * \\
(4.93)\end{array}$ \\
\hline Number of Observations & 588 & 588 & 588 & 588 \\
\hline Adj. R-square & 0.706 & 0.665 & 0.715 & 0.469 \\
\hline Country effects & Yes & Yes & Yes & Yes \\
\hline Year fixed effects & Yes & Yes & Yes & Yes \\
\hline
\end{tabular}

Note: The dependent variables are cost of capital measures (HRRm, rCred, CERP and DY) as described in Table 1 . The key independent variable is CPIS_FB also described in Table 1 above. All the controls are the same as described in Table 3. All t-statistics reported are based on Newey-West autocorrelation and heteroskedasticitycorrected standard errors. For tractable interpretation, all the coefficients are reported as elasticity and the statistical significance is reported against $10 \%(*), 5 \%(* *)$ and $1 \%(* * *)$ significance levels. 
Table 5

The relation between equity foreign bias using global fund and the four cost of capital proxies

\begin{tabular}{|c|c|c|c|c|}
\hline Cost of capital proxy & $\begin{array}{l}\text { Model (1) } \\
\text { HRRm }\end{array}$ & $\begin{array}{l}\text { Model (2) } \\
\text { rCred }\end{array}$ & $\begin{array}{c}\text { Model (3) } \\
\text { CERP }\end{array}$ & $\begin{array}{l}\text { Model (4) } \\
\text { DY }\end{array}$ \\
\hline GF_FB & $\begin{array}{c}-0.874 * * * \\
(-4.45)\end{array}$ & $\begin{array}{c}-0.570 * * * \\
(-7.56)\end{array}$ & $\begin{array}{c}-0.485 * * * \\
(-3.81)\end{array}$ & $\begin{array}{c}-0.307 * * * \\
(-3.77)\end{array}$ \\
\hline MKTCap & $\begin{array}{c}-0.769 * * * \\
(-5.83)\end{array}$ & $\begin{array}{l}-0.285 * * * \\
(-3.42)\end{array}$ & $\begin{array}{c}-0.291 * * * \\
(-5.18)\end{array}$ & $\begin{array}{c}-0.650 * * * \\
(-6.03)\end{array}$ \\
\hline Beta & $\begin{array}{c}0.765 * * * \\
(7.13)\end{array}$ & $\begin{array}{c}0.337 * * * \\
(4.21)\end{array}$ & $\begin{array}{c}0.274 * * * \\
(6.46)\end{array}$ & $\begin{array}{c}0.745^{*} \\
(1.69)\end{array}$ \\
\hline $\mathrm{BM}$ & $\begin{array}{c}0.418 * * * \\
(5.51)\end{array}$ & $\begin{array}{c}0.331 * * * \\
(4.68)\end{array}$ & $\begin{array}{l}0.954 \\
(0.69)\end{array}$ & $\begin{array}{l}0.731 \\
(0.76)\end{array}$ \\
\hline Retn_1 & $\begin{array}{l}-0.364 \\
(-1.42)\end{array}$ & $\begin{array}{l}-0.466 \\
(-1.26)\end{array}$ & $\begin{array}{c}-0.252^{*} \\
(-1.81)\end{array}$ & $\begin{array}{c}-0.612 * * \\
(-2.19)\end{array}$ \\
\hline Exch & $\begin{array}{c}0.317^{*} \\
(1.64)\end{array}$ & $\begin{array}{c}0.363^{*} \\
(1.81)\end{array}$ & $\begin{array}{c}0.556^{* *} \\
(2.59)\end{array}$ & $\begin{array}{l}0.702 * * * \\
(4.27)\end{array}$ \\
\hline Infl & $\begin{array}{c}-0.308 * * * \\
(-4.40)\end{array}$ & $\begin{array}{l}-0.440 * * \\
(-2.55)\end{array}$ & $\begin{array}{c}-0.476^{* * * *} \\
(-3.13)\end{array}$ & $\begin{array}{l}0.698 \\
(0.95)\end{array}$ \\
\hline Turn & $\begin{array}{c}-0.551 * * * \\
(-11.82)\end{array}$ & $\begin{array}{c}-0.372 * * * \\
(-9.74)\end{array}$ & $\begin{array}{c}-0.235^{* * *} \\
-(9.54)\end{array}$ & $\begin{array}{c}-0.266^{*} \\
(-1.75)\end{array}$ \\
\hline LSMI & $\begin{array}{c}-0.394 * * \\
(-2.16)\end{array}$ & $\begin{array}{c}-0.565^{*} \\
(-1.68)\end{array}$ & $\begin{array}{c}-0.603 * * * \\
(-4.77)\end{array}$ & $\begin{array}{c}-0.876^{* *} \\
(-2.75)\end{array}$ \\
\hline RGDPG & $\begin{array}{c}-0.965^{*} \\
(-1.80)\end{array}$ & $\begin{array}{c}-0.745^{* *} \\
(-2.79)\end{array}$ & $\begin{array}{c}-0.359 * * * \\
(-6.82)\end{array}$ & $\begin{array}{c}-0.453 * * \\
(-2.88)\end{array}$ \\
\hline Law & $\begin{array}{c}-0.562 * * * \\
(-7.04)\end{array}$ & $\begin{array}{c}-0.642 * * * \\
(-4.83)\end{array}$ & $\begin{array}{c}-0.555^{* *} \\
(-2.62)\end{array}$ & $\begin{array}{c}-0.526^{* *} \\
(-2.73)\end{array}$ \\
\hline PolRisk & $\begin{array}{c}0.471 * * * \\
(5.22)\end{array}$ & $\begin{array}{c}0.326^{* * * *} \\
(6.90)\end{array}$ & $\begin{array}{c}0.547 * * * \\
(3.77)\end{array}$ & $\begin{array}{c}0.480 * * \\
(2.79)\end{array}$ \\
\hline EconRisk & $\begin{array}{c}0.368^{* * *} \\
(2.09)\end{array}$ & $\begin{array}{c}0.561 * * * \\
(3.58)\end{array}$ & $\begin{array}{c}0.380 * * \\
(2.73)\end{array}$ & $\begin{array}{c}0.696^{* *} \\
(2.11)\end{array}$ \\
\hline FinRisk & $\begin{array}{l}0.483 \\
(0.38)\end{array}$ & $\begin{array}{l}0.986 \\
(1.22)\end{array}$ & $\begin{array}{l}0.352 \\
(0.83)\end{array}$ & $\begin{array}{l}0.482 \\
(1.16)\end{array}$ \\
\hline SMB & $\begin{array}{c}0.290 * * \\
(2.14)\end{array}$ & $\begin{array}{c}0.295 * * \\
(2.67)\end{array}$ & $\begin{array}{c}0.253 * * * \\
(3.88)\end{array}$ & $\begin{array}{c}0.270 * * \\
(2.83)\end{array}$ \\
\hline HML & $\begin{array}{c}0.544 * * * \\
(3.18)\end{array}$ & $\begin{array}{c}0.381 * * \\
(2.32)\end{array}$ & $\begin{array}{c}0.329 * * * \\
(3.24)\end{array}$ & $\begin{array}{c}0.254 * * \\
(2.78)\end{array}$ \\
\hline Constant & $\begin{array}{c}0.521 * * * \\
(5.47)\end{array}$ & $\begin{array}{c}0.647 * * * \\
(7.56)\end{array}$ & $\begin{array}{c}0.356 * * * \\
(9.48)\end{array}$ & $\begin{array}{c}0.592 * * * \\
(6.89)\end{array}$ \\
\hline Number of Observations & 588 & 588 & 588 & 588 \\
\hline Adj. R-square & 0.662 & 0.686 & 0.631 & 0.717 \\
\hline Country effects & Yes & Yes & Yes & Yes \\
\hline Year fixed effects & Yes & Yes & Yes & Yes \\
\hline
\end{tabular}


Table 6

The relation between foreign bias, home bias, country bias and Tobin's Q

\begin{tabular}{|c|c|c|c|}
\hline & $\begin{array}{l}\text { Model (1) } \\
\text { Tobin's Q }\end{array}$ & $\begin{array}{l}\text { Model (2) } \\
\text { Tobin's Q }\end{array}$ & $\begin{array}{l}\text { Model (3) } \\
\text { Tobin's Q }\end{array}$ \\
\hline CPIS_HB & $\begin{array}{c}-0.562 * * * \\
(-9.60)\end{array}$ & & \\
\hline CPIS_FB & & $\begin{array}{c}0.813 * * * \\
(5.49)\end{array}$ & \\
\hline GF_FB & & & $\begin{array}{l}0.448 * * * \\
(5.73)\end{array}$ \\
\hline MKTCap & $\begin{array}{c}-0.652 * * * \\
(-21.47)\end{array}$ & $\begin{array}{l}-0.524 * * * \\
(-18.84)\end{array}$ & $\begin{array}{l}-0.648 * * * \\
(-20.13)\end{array}$ \\
\hline Beta & $\begin{array}{c}-0.356^{*} \\
(-1.97)\end{array}$ & $\begin{array}{l}-0.235 \\
(-1.41)\end{array}$ & $\begin{array}{l}-0.144 \\
(-0.88)\end{array}$ \\
\hline BM & $\begin{array}{c}-0.324 * * \\
(-2.27)\end{array}$ & $\begin{array}{c}-0.611^{* * * *} \\
(-4.85)\end{array}$ & $\begin{array}{l}-0.812^{* * *} \\
(-5.68)\end{array}$ \\
\hline Retn_1 & $\begin{array}{c}0.726^{*} \\
(1.85)\end{array}$ & $\begin{array}{l}0.644 \\
(1.33)\end{array}$ & $\begin{array}{l}0.523 \\
(1.22)\end{array}$ \\
\hline Exch & $\begin{array}{c}-0.460 * * \\
(-2.07)\end{array}$ & $\begin{array}{c}-0.529 * * * \\
(-3.23)\end{array}$ & $\begin{array}{c}-0.484 * * \\
(-2.15)\end{array}$ \\
\hline Infl & $\begin{array}{c}-0.435 * \\
(-1.72)\end{array}$ & $\begin{array}{l}-0.480 \\
(-1.43)\end{array}$ & $\begin{array}{l}-0.591 * \\
(-1.95)\end{array}$ \\
\hline Turn & $\begin{array}{c}0.276^{* *} \\
(2.21)\end{array}$ & $\begin{array}{c}0.428 * * * \\
(4.62)\end{array}$ & $\begin{array}{c}0.317 * * \\
(2.87)\end{array}$ \\
\hline LSMI & $\begin{array}{c}-0.706^{* * *} \\
(-6.28)\end{array}$ & $\begin{array}{c}-0.812 * * * \\
(-7.56)\end{array}$ & $\begin{array}{l}-0.735^{* * *} \\
(-8.63)\end{array}$ \\
\hline RGDPG & $\begin{array}{c}-0.585 * * \\
(-2.19)\end{array}$ & $\begin{array}{l}-0.634 \\
(-1.12)\end{array}$ & $\begin{array}{c}-0.345^{*} \\
(-1.66)\end{array}$ \\
\hline Law & $\begin{array}{c}0.338 * * \\
(2.44)\end{array}$ & $\begin{array}{c}0.347 * * * \\
(3.19)\end{array}$ & $\begin{array}{l}0.468^{*} \\
(1.72)\end{array}$ \\
\hline PolRisk & $\begin{array}{c}0.677 * * * \\
(6.29)\end{array}$ & $\begin{array}{l}0.553^{* * *} \\
(4.61)\end{array}$ & $\begin{array}{l}0.582 * * * \\
(5.39)\end{array}$ \\
\hline EconRisk & $\begin{array}{c}-0.433 * * * \\
(-3.76)\end{array}$ & $\begin{array}{c}-0.388^{*} \\
(-1.97)\end{array}$ & $\begin{array}{c}-0.267 * * \\
(-2.23)\end{array}$ \\
\hline FinRisk & $\begin{array}{c}-0.318^{* *} \\
(-2.30)\end{array}$ & $\begin{array}{l}-0.510^{*} \\
(-1.77)\end{array}$ & $\begin{array}{c}-0.465^{*} \\
(-1.72)\end{array}$ \\
\hline Constant & $\begin{array}{l}0.746^{* * *} \\
(14.03)\end{array}$ & $\begin{array}{l}0.829 * * * \\
(12.68)\end{array}$ & $\begin{array}{l}0.732 * * * \\
(13.23)\end{array}$ \\
\hline Number of Observations & 594 & 594 & 594 \\
\hline Adj. R-square & 0.632 & 0.661 & 0.604 \\
\hline Country effects & Yes & Yes & Yes \\
\hline Year fixed effects & Yes & Yes & Yes \\
\hline \multicolumn{4}{|c|}{$\begin{array}{l}\text { Note: The dependent variable Tobin's } Q \text { is measured as the log book value of total liabilities plus market value of } \\
\text { equity and divided by the book value of assets of country } i \text {. The key independent variables are CPIS_HB, CPIS_FB } \\
\text { and GF_FB, also described in Table } 1 \text {. All the controls are the same as described in Table } 3 \text {. All t-statistics } \\
\text { reported are based on Newey-West autocorrelation and heteroskedasticity-corrected standard errors. For tractable } \\
\text { interpretation, all the coefficients are reported as elasticity and the statistical significance is reported against } 10 \% \\
(*), 5 \%(* *) \text { and } 1 \%(* * *) \text { significance levels. }\end{array}$} \\
\hline
\end{tabular}


Table 7

Robustness tests.

Panel A: Using one-year lag values

\begin{tabular}{|c|c|c|c|c|}
\hline & $\begin{array}{l}\text { Model (1) } \\
\text { HRRm }\end{array}$ & $\begin{array}{l}\text { Model (2) } \\
\text { rCred }\end{array}$ & $\begin{array}{c}\text { Model (3) } \\
\text { CERP }\end{array}$ & $\begin{array}{l}\text { Model (4) } \\
\text { DY }\end{array}$ \\
\hline CPIS_HB_1 & $\begin{array}{c}0.764 * * * \\
(5.87)\end{array}$ & $\begin{array}{c}0.492 * * * \\
(6.90)\end{array}$ & $\begin{array}{c}0.390 * * * \\
(5.73)\end{array}$ & $\begin{array}{c}0.247^{* * *} \\
(4.86)\end{array}$ \\
\hline CPIS_FB_1 & $\begin{array}{c}-0.766^{* * *} \\
(-5.25)\end{array}$ & $\begin{array}{c}-0.490 * * * \\
(-5.54)\end{array}$ & $\begin{array}{c}-0.548 * * * \\
(-11.02)\end{array}$ & $\begin{array}{c}-0.369 * * * \\
(-6.13)\end{array}$ \\
\hline GF_FB_1 & $\begin{array}{c}-0.386 * * * \\
(-5.73)\end{array}$ & $\begin{array}{c}-0.655 * * * \\
(-6.87)\end{array}$ & $\begin{array}{c}-0.577 * * * \\
(-4.31)\end{array}$ & $\begin{array}{c}-0.448 * * * \\
(-5.35)\end{array}$ \\
\hline
\end{tabular}

Panel B: Dynamic GMM

\begin{tabular}{lcccc}
\hline & Model (1) & Model (2) & Model (3) & \multicolumn{2}{c}{ Model (4) } \\
& HRRm & rCred & CERP & DY \\
\hline CPIS_HB_1 & $0.849^{* * *}$ & $0.405 * * *$ & $0.502^{* * *}$ & $0.580^{* * *}$ \\
& $(7.25)$ & $(11.16)$ & $(8.84)$ & $(7.39)$ \\
CPIS_FB_1 & $-0.973^{* * *}$ & $-0.504 * * *$ & $-0.648^{* * *}$ & $-0.471^{* * *}$ \\
& $(-5.32)$ & $(-11.78)$ & $(-10.66)$ & $(-4.49)$ \\
GF_FB_1 & $-0.950^{* * *}$ & $-0.657 * * *$ & $-0.651^{* * *}$ & $-0.427 * * *$ \\
& $(-5.87)$ & $(-10.34)$ & $(-6.46)$ & $(-5.83)$ \\
AR (2) & 0.45 & 0.63 & 0.62 & 0.81 \\
Hansen J statistics & 0.52 & 0.58 & 0.55 & 0.70 \\
Difference Hansen J statistics & 0.69 & 0.76 & 0.71 & 0.64 \\
Controls including country & & & & Yes \\
and year fixed effects & Yes & Yes & & Yes \\
\hline
\end{tabular}

Panel C: Heckman selection estimation

\begin{tabular}{lcccc}
\hline CPIS_HB & $0.815^{* * *}$ & $0.391 * * *$ & $0.354 * * *$ & $0.244 * * *$ \\
& $(5.76)$ & $(6.34)$ & $(5.68)$ & $(4.52)$ \\
CPIS_FB & $-0.728^{* * *}$ & $-0.405 * * *$ & $-0.391 * * *$ & $-0.186^{* * *}$ \\
& $(-5.67)$ & $(-5.53)$ & $(-6.64)$ & $(-3.69)$ \\
GF_FB & $-0.670 * * *$ & $-0.328 * * *$ & $-0.745 * * *$ & $-0.347 * * *$ \\
& $(-5.79)$ & $(-13.45)$ & $(-7.32)$ & $(-7.24)$ \\
\hline
\end{tabular}

Note: The dependent variables are cost of capital measures (HRRm, rCred, CERP and DY) as described in Table 1. The key independent variables are is one year lagged $C P I S_{-} H B, C P I S \_F B$, and $G F_{-} F B$, also described in Table 1. Panel A reports the coefficients of the lagged values, Panel B reports the coefficients of Dynamic GMM estimation and panel $\mathrm{C}$ reports the estimates of Heckman selection model. All the controls are the same as described in Table 3. All t-statistics reported are based on Newey-West autocorrelation and heteroskedasticity-corrected standard errors. For tractable interpretation, all the coefficients are reported as elasticity and the statistical significance is reported against $10 \%(*), 5 \%(* *)$ and $1 \%(* * *)$ significance levels. 